\title{
Depressive-Like Behaviors Are Regulated by NOX1/NADPH Oxidase by Redox Modification of NMDA Receptor 1
}

\author{
Dasakazu Ibi, ${ }^{1}$ Junjie Liu, ${ }^{1}$ Noriaki Arakawa, ${ }^{5}$ Shiho Kitaoka, ${ }^{6}$ Ai Kawaji, ${ }^{1}$ Ken-ichi Matsuda, ${ }^{2}$ Kazumi Iwata, ${ }^{1}$ \\ Misaki Matsumoto, ${ }^{1}{ }^{\circledR}$ Masato Katsuyama, ${ }^{4}$ Kai Zhu, ${ }^{1}$ Satoshi Teramukai, ${ }^{3}$ Tomoyuki Furuyashiki, ${ }^{6}$ \\ and Chihiro Yabe-Nishimura ${ }^{1}$ \\ Departments of ${ }^{1}$ Pharmacology, ${ }^{2}$ Anatomy and Neurobiology, and ${ }^{3}$ Biostatistics, and ${ }^{4}$ Radioisotope Center, Kyoto Prefectural University of Medicine, Kyoto \\ 602-8566, Japan, ${ }^{5}$ Department of Medical Life Science, Graduate School of Medical Life Science, Yokohama City University, Yokohama 236-0004, Japan, and \\ ${ }^{6}$ Division of Pharmacology, Kobe University Graduate School of Medicine, Kobe 650-0017, Japan
}

Involvement of reactive oxygen species (ROS) has been suggested in the development of psychiatric disorders. NOX1 is a nonphagocytic form of NADPH oxidase whose expression in the nervous system is negligible compared with other NOX isoforms. However, NOX1derived ROS increase inflammatory pain and tolerance to opioid analgesia. To clarify the role of NOX1 in the brain, we examined depressive-like behaviors in mice deficient in $\operatorname{Noxl}\left(\operatorname{Noxl}^{-/ \mathrm{Y}}\right)$. Depressive-like behaviors induced by chronic social defeat stress or administration of corticosterone (CORT) were significantly ameliorated in $\mathrm{Noxl}^{-/ \mathrm{Y}}$. Generation of ROS was significantly elevated in the prefrontal cortex (PFC) of mice administrated with CORT, while NOX1 mRNA was upregulated only in the ventral tegmental area (VTA) among brain areas responsible for emotional behaviors. Delivery of miRNA against NOX1 to VTA restored CORT-induced depressive-like behaviors in wild-type (WT) littermates. Administration of CORT to WT, but not to Nox $1^{-/ Y}$, significantly reduced transcript levels of brain-derived neurotrophic factor $(b d n f)$, with a concomitant increase in DNA methylation of the promoter regions in $b d n f$. Delivery of miRNA against NOX1 to VTA restored the level of BDNF mRNA in WT PFC. Redox proteome analyses demonstrated that NMDA receptor 1 (NR1) was among the molecules redox regulated by NOX1. In cultured cortical neurons, hydrogen peroxide significantly suppressed NMDA-induced upregulation of BDNF transcripts in NR1-expressing cells but not in cells harboring mutant NR1 (C744A). Together, these findings suggest a key role of NOX1 in depressive-like behaviors through NR1-mediated epigenetic modification of $b d n f$ in the mesoprefrontal projection.

Key words: BDNF; depressive-like behavior; mesoprefrontal projection; NADPH oxidase; NMDA receptor; redox

Significance Statement

NADPH oxidase is a source of reactive oxygen species (ROS) that have been implicated in the pathogenesis of various neurological disorders. We presently showed the involvement of a nonphagocytic type of NADPH oxidase, NOX1, in major depressive disorders, including behavioral, biochemical, and anatomical changes in mice. The oxidation of NR1 by NOX1-derived ROS was demonstrated in prefrontal cortex (PFC), which may be causally linked to the downregulation of BDNF, promoting depressive-like behaviors. Given that NOX1 is upregulated only in VTA but not in PFC, mesocortical projections appear to play a crucial role in NOX1-dependent depressive-like behaviors. Our study is the first to present the potential molecular mechanism underlying the development of major depression through the NOX1-induced oxidation of NR1 and epigenetic modification of $b d n f$.

\section{Introduction}

Chronic stress precipitates the development of major depressive disorder (MDD), but underlying molecular mechanisms remain

Received Sept. 23, 2016; revised March 6, 2017; accepted March 11, 2017.

Author contributions: M.I., S.K., K.I., M.K., K.Z., T.F., and C.Y.-N. designed research; M.I., J.L., N.A., and A.K. performed research; S.K., K.-i.M., M.M., and T.F. contributed unpublished reagents/analytic tools; M.I., J.L., N.A., A.K., and S.T. analyzed data; M.I. and C.Y.-N. wrote the paper.

This work was supported by Grant-in-Aid for Young Scientists (B) 22700397, Grant-in-Aid for Scientific Research (C) 24500445, and Grant-in-Aid for Scientific Research on Innovative Areas 25116521 from the Ministry of Education, Culture, Sports, Science and Technology of Japan (M.I.). elusive. The postmortem findings demonstrate structural alterations in the nervous system, namely, reduction in the volume and reduced expression of synaptic proteins in prefrontal cortex

C.Y.-N. reports having received research funding from Actelion Pharmaceuticals Japan Ltd. and Sanwa Kagaku Kenkyusho $\mathrm{C}$. Ltd. She is a cofounder of a startup company developing NOX inhibitors. The authors declare no othe competing financial interests.

Correspondence should be addressed to Dr. Chihiro Yabe-Nishimura, Department of Pharmacology, Kyoto Prefectural University of Medicine, Kamigyo-ku, Kyoto 602-8566, Japan. E-mail: nchihiro@koto.kpu-m.ac.jp. DOI:10.1523/JNEUROSCI.2988-16.2017

Copyright $\odot 2017$ the authors $\quad 0270-6474 / 17 / 374200-13 \$ 15.00 / 0$ 
(PFC) and the hippocampus (Price and Drevets, 2010, 2012). In rodents, chronic stress decreases dendrite branching and the spine density in PFC and hippocampus (Radley et al., 2004, 2006), and these alterations are associated with depressive-like behaviors (Duman and Duman, 2015; McEwen et al., 2016).

In MDD, brain-derived neurotrophic factor (BDNF) has been shown to play an important role in adaptation to stress or antidepressants (Shimizu et al., 2003). The structural and behavioral changes observed in animal models exposed to chronic stress are currently attributed to the altered expression of BDNF. The structure of the $b d n f$ gene is complex, in that there are several $5^{\prime}$ noncoding exons, each of which has its own promoter giving rise to several transcripts, all coding the same BDNF protein. A specific downregulation of $b d n f$ exons through epigenetic modifications of their respective promoters is observed in MDD patients as well as in the hippocampus and PFC of rodents subjected to stress (Tsankova et al., 2006; Januar et al., 2015). Oxidative stress has been implicated in the pathology of depression in humans and animal models (Maes et al., 2011; Zlatković et al., 2014). Several studies documented that chronic stress-induced oxidative stress is attributed to a deranged antioxidant system with the increased production of reactive oxygen species (ROS; Maes et al., 2011). NADPH oxidase is a superoxide-generating flavoenzyme comprising the membrane-bound catalytic subunit NOX, $\mathrm{p} 22^{\text {phox }}$, and several cytosolic regulatory subunits including $\mathrm{p} 47^{\text {phox }}$ and $\mathrm{p} 67^{\text {phox }}$. Among several NOX homologs, a phagocytic isoform, NOX2, was shown to be involved in the pathogenesis of neurodegenerative and psychiatric disorders (Sorce and Krause, 2009). During the course of this study, the involvement of NADPH oxidase in depression was reported in mice subjected to restraint stress. Repeated immobilization in restraints upregulated the expression of $\mathrm{p} 47^{\text {phox }}$, a cytosolic subunit of NADPH oxidase in the hippocampus, and heterozygous deletion of $p 47^{\text {hox }}$ ameliorated depressive behaviors (Seo et al., 2012).

NOX1 is a nonphagocytic form of NADPH oxidase whose expression in the nervous system is less abundant compared with other NOX isoforms. However, NOX1-derived ROS increase inflammatory pain and tolerance to opioid analgesia (Ibi et al., 2008, 2011). To clarify the significance of NOX1 expressed in brain regions, we set out to examine the role of NOX1 in depressive-like behaviors induced by chronic stress or by the administration of corticosteroid, which is elevated in the plasma of MDD patients. The characteristic hallmarks of MDD demonstrated in wild-type littermates were significantly abrogated in mice deficient in Nox1 $\left(N o x 1^{-/ Y}\right)$. With a mechanistic link between depressive-like behaviors and the NMDA receptor 1 (NR1)-BDNF signaling axis in the mesoprefrontal projection, the present study reveals a novel role for NOX1 in psychiatric disorders.

\section{Materials and Methods}

Animals. Nox1 $1^{-/ Y}$ mice on a C57BL/6J genetic background and control littermates [wild type (WT)] were generated in our laboratory (Matsuno et al., 2005) and housed in a temperature-controlled room $\left(21-23^{\circ} \mathrm{C}\right)$ with a $12 \mathrm{~h}$ light/dark cycle under specific pathogen-free conditions with free access to tap water and normal chow. For behavioral studies, 8-week-old mice were used. All procedures were conducted in accordance with the policies and recommendations of the International Association for the Study of Pain and were approved by the Committee for Animal Research at Kyoto Prefectural University of Medicine.

Chronic social defeat stress was applied as described previously (Berton et al., 2006) with minor modifications. Briefly, each mouse was exposed to an unfamiliar aggressive male CD1 mouse once a day for 10 min. After interaction, mice were placed in an adjacent compartment of the same cage for $24 \mathrm{~h}$ with sensory, but not physical, contact. Mice were subjected to the social defeat stress for 11 consecutive days. The control mice were housed in an equivalent cage without interaction with CD1 mice. The experiments were performed in animal facility usually starting at 9:00 A.M.

Chronic stress elicits dysregulation of the hypothalamic-pituitaryadrenal axis and the resultant increase in blood cortisol levels are involved in the pathogenesis of depression (Johnson et al., 2006). To generate a rodent model of MDD, corticosterone (CORT; Wako) was dissolved in drinking water $(35 \mu \mathrm{g} / \mathrm{ml})$ and supplied to mice for $21-24 \mathrm{~d}$ (Dwivedi et al., 2006; Gourley et al., 2013). An inhibitor of NADPH oxidase and an antioxidant, apocynin (Apo), was administered to WT mice for $21 \mathrm{~d}$ in tap water $(2 \mathrm{mg} / \mathrm{ml})$, as described previously (Ibi et al., 2011).

Behavioral analyses. For the forced swim test (FST), mice were individually placed in a glass container (diameter, $13.5 \mathrm{~cm}$; height, $19 \mathrm{~cm}$ ) containing tap water at $23^{\circ} \mathrm{C}$. The water depth was $14 \mathrm{~cm}$, which prevented the mice from touching the bottom with their paws or tail. Each mouse was tested for $5 \mathrm{~min}$, and the period of immobility during the time was measured by a trained observer. For the tail suspension test (TST), each mouse was suspended by its tail with tape, and the period of immobility during 5 min was measured by a trained observer. The experiments were performed in an animal facility usually starting at 9:00 A.M.

Social interaction was evaluated as previously reported (Berton et al., 2006) with minor modifications. Experiments were performed at $24 \mathrm{~h}$ after the final day of exposure to CD1 mice or at 3 weeks after the start of administration of CORT. A gray plastic open field apparatus $(35 \times 35$ $\mathrm{cm}$ ) maintained at 10 lux was used. A social interaction test was performed in two consecutive sessions of $3 \mathrm{~min}$. During the first session (no target), the open field contained an empty clear plastic container with holes (at $3 \mathrm{~cm}$ from the ground) located in the wall of the apparatus. During the second session (target), the conditions were identical except that a social target animal (CD1) was introduced into the cage. Between the two sessions, the experimental mouse was removed from the apparatus and was placed back in its home cage for $\sim 1 \mathrm{~min}$. The time spent in the interaction zone (a 5-cm-wide area surrounding the container) was measured.

To evaluate anhedonia caused by long-term exposure to CORT, the sucrose preference test was performed on the next day after the evaluation of social interaction. For $48 \mathrm{~h}$, each mouse placed in one cage, was given a choice between two bottles, one with $1 \%$ sucrose solution and the other with tap water. To prevent the possible effects of side preference in drinking behavior, the position of the bottle was switched every $12 \mathrm{~h}$. The preference for sucrose was calculated using the following formula: sucrose preference $=100 \times$ volume (consumption of sucrose) $/[$ volume (consumption of sucrose) + volume (consumption of water)].

A range of 4-29 animals was studied per experimental group. Animals were randomly assigned to treatment in each experimental analysis. The order in which the animals in the experimental group were treated was randomly determined. For behavioral studies, experimenters were masked to the group assignment.

Measurement of corticosterone levels. The level of corticosterone in plasma was measured using the Corticosterone EIA kit (Enzo Life Sciences) according to the instructions of the manufacturer. The blood was collected during the diurnal surge, $60 \mathrm{~min}$ before lights off.

Detection of superoxide. Superoxide production was measured with the L012 Chemiluminescence Assay using Luminescensor (Atto), as previously described (Ibi et al., 2011).

Imaging of dihydroethidium oxidation. ROS production was assessed using dihydroethidium (DHE) as previously described (Hall et al., 2012) with minor modifications. Mice were perfused with $4 \%$ paraformaldehyde (PFA) at $24 \mathrm{~h}$ after the administration of DHE $(25 \mathrm{mg} / \mathrm{kg}$, i.p.). Dissected brain tissue placed in chilled 2\% PFA for $48 \mathrm{~h}$ was processed in $70 \mu \mathrm{m}$ floating sections and was maintained in $2 \%$ PFA for an additional $48 \mathrm{~h}$. Fluorescence images of DHE oxidation were captured using a confocal laser microscope (FV1000, Olympus). Evaluation of DHE oxidation was performed as previously described (Quick et al., 2008) with minor modifications. More than 30 neurons in the PFC region were determined, and mean fluorescence intensity was obtained from four mice. 
Quantitative PCR. Total RNA was extracted using Sepasol (Nacalai Tesque) or NucleoSpin RNA (Macherey-Nagel). Reverse transcription was performed with the PrimeScript RT reagent Kit (TAKARA) according to the instructions. Real-time PCR was performed using StepOnePlus (Applied Biosystems) with SYBR Premix EX Taq II (TAKARA). The primer sequences used for the determination of NOX transcripts were the same as previously described (Cui et al., 2011; Ibi et al., 2011). For p22phox, 5' -GCC ATT GCC AGT GTG ATC TA-3', 5' -ACC CTC ACT CGG CTT CTT TC-3'; p47phox, 5' -CCA ACT ACG CAG GTG AAC CGT A-3', 5'-CAG CCT TCT GCA GAT ACA TGG ATG-3'; p67phox, 5'-GCT GAT AGA CTA CAA GAT CCT GG-3', 5' -TGT CCA TTG AAC ATG ACT GTG GC-3'; rac1, 5' -TAT GGG ACA CAG CTG GAC AA-3', 5'-ACA GTG GTG TCG CAC TTC AG-3'; total BDNF mRNA, 5' -GAG GGC TCC TGC TTC TCA A-3', 5'-GCC TTC ATG CAA CCG AAG T- $3^{\prime}$; exon IV of the $b d n f$ gene, $5^{\prime}$-CTT CCT TGA GCC CAG TTC C- $3^{\prime}$, $5^{\prime}$-CCC GTG GAC GTT TAC TTC TTT C-3'; NR1, 5' -CTG CAA CCC TCA CTT TTG AG-3', 5' -TGC AAA AGC CAG CTG CAT CT-3'; NMDA receptor 2B (NR2B), 5'-GTG AGA GCT CCT TTG CCA AC-3', 5'-GTC AGG GTA GAG CGA CTT GC-3'; and N-ethylmaleimidesensitive fusion (NSF), 5'-GCA TTT GCT TCT CGG GTG TTC-3', 5' CTC CTC TTC GGC ATC AGC AA-3'. Expression was performed by a relative ratio of each transcript to that of hypoxanthine-guanine phosphoribosyltransferase used as the endogenous internal control.

Silencing of NOX1 with miRNA. To knock down endogenous NOX1 in ventral tegmental area (VTA) and prefrontal cortex (PFC), the BLOCK-IT Poll II miR RNAi Expression Vector kit (Invitrogen) was applied. The sequence of miRNA to target the coding region of NOX1 was determined by RNAi Designer (Invitrogen), as follows: top_NOX1, 5' -TGC TGT GAA GTA GAA CTG AAC CTT CCG TTT TGG CCA CTG ACT GAC GGA AGG TTG TTC TAC TTC A-3', and bottom_NOX1, 5' -CCT GTG AAG TAG AAC AAC CTT CCG TCA GTC AGT GGC CAA AAC GGA AGG TTC AGT TCT ACT TCA C-3'; or top_NOX1, 5' -TGC TGT TAG ATG GGT GCA TGA CAA CCG TTT TGG CCA CTG ACT GAC GGT TGT CAC ACC CAT CTA A-3', and bottom_NOX1, 5' -CCT GTT AGA TGG GTG TGA CAA CCG TCA GTC AGT GGC CAA AAC GGT TGT CAT GCA CCC ATC TAA C-3'. The annealed double-strand oligo was cloned into the pcDNA6.2-GW/EmGFP-miR vector. The control plasmid (pcDNA6.2-GW/EmGFP-miR-neg) containing an insert that forms a hairpin structure as the pre-miRNA, but is predicted not to target any known vertebrate genes, was used as a negative control. The miRNA expression constructs were subcloned into pAAV-EF1 $\alpha$-DIOEYFP for stable miRNA delivery. Following triple transfection of HEKadeno-associated virus (AAV) cells with pAAV-miRNA/NOX1 or pAAV-miRNA/NC, a pHelper plasmid, and pAAV2/rh10 expressing the rep gene of AAV2 and cap genes of AAV2/rh10 (provided by Dr. Julie Johnston, University of Pennsylvania, Philadelphia, PA), AAV2/rh10 virus expressing miRNA targeting NOX1 (miRNA/NOX1) or neg-miRNA (miRNA/NC) was produced. Mice were mounted in a stereotaxic apparatus, and virus was injected into VTA or PFC (Chaudhury et al., 2013). AAV2/rh10 was delivered to VTA or PFC by two midline injections: anteroposterior (AP), $-3.3 \mathrm{~mm}$; mediolateral (ML), $\pm 0.5 \mathrm{~mm}$; dorsoventral (DV), $-4.5 \mathrm{~mm}$ from the bregma; or at AP, $+1.9 \mathrm{~mm}$; ML, \pm 0.5 $\mathrm{mm}$; DV,$-2.6 \mathrm{~mm}$ from the bregma. The needle was left in the place for $8 \mathrm{~min}$ before removal, and the scalp incision was sutured. At 3 weeks after viral injection, CORT was administered to the mice.

Construction of lentiviruses harboring NR1 or mutant NR1. A cDNA clone encoding NR1 was isolated from the mouse brain. Substitution of Cys ${ }^{744}$ with Ala $(\mathrm{C} 744 \mathrm{~A})$ in NR1 was performed by site-directed mutagenesis using the PCR overlap-extension method and was confirmed by DNA sequencing. To create lentiviruses encoding wild-type or mutant NR1, cDNA clones were inserted into pCDH-CMV-MCS-EF1-GreenPuro (System Biosciences). Following the transfection of Lenti-X cells with pCDH-NR1 or pCDH-NR1(C744A) in the presence of a pNHP plasmid, pVSV-G, and pCEP4-tat, lentiviruses expressing NR1 or NR1(C744A) were generated. The preparation of lentivirus was performed as previously described (Tiscornia et al., 2006).

Immunohistochemistry. Cryosections were incubated with $1 \%$ rabbit serum for $1 \mathrm{~h}$ followed by reaction with an anti-GFP antibody (1:3000; catalog \#04404-26, Nacalai Tesque; RRID:AB_2313652) overnight at $4^{\circ} \mathrm{C}$. After reaction, sections were incubated with biotinylated anti-rat $\operatorname{IgG}(1: 1000)$, and the expression of GFP was detected by the avidinbiotin complex-diaminobenzidine methods, as previously described (Ibi et al., 2011).

Primary culture. The forebrain of the fetal mouse at 14-15 d of gestation was dissected, minced, and treated with $0.25 \%$ trypsin-EDTA for 10 $\min$ at $37^{\circ} \mathrm{C}$. Cell suspensions plated on $0.1 \%$ poly-L-lysine-coated dishes were maintained in Neurobasal Medium containing B27 supplement (NB/B27) and $1 \%$ FBS. On the next day [day in vitro 2 (DIV2)], neuronal cultures were supplied for transduction with AAV2/rh10 or a lentivirus for $24 \mathrm{~h}$ in NB/B27. To confirm the efficacy of miRNA to suppress NOX1 mRNA, cultured neurons were transduced with AAV2/rh10 expressing miRNA [multiplicity of infection (MOI), $10^{6}$ ], and total RNA was isolated at DIV21. To generate cortical neurons expressing wild-type or mutant NR1, cultured cells were infected with lentiviruses encoding NR1 or NR1 (C744A; MOI, 10). At DIV10, cells were exposed to NMDA in the presence or absence of hydrogen peroxide $\left(\mathrm{H}_{2} \mathrm{O}_{2}\right)$ for $6 \mathrm{~h}$, after which BDNF mRNA levels were determined (Tian et al., 2009). Because antioxidants present in $\mathrm{B} 27$ may scavenge the $\mathrm{H}_{2} \mathrm{O}_{2}$, cells were treated in $\mathrm{NB}$ without B27 supplementation.

Golgi-Cox staining. Coronal brain sections $(200 \mu \mathrm{m})$ cut on a cryostat (Leica) were mounted on a slide glass. Golgi-Cox staining was performed using the FD Rapid GolgiStain kit (FD NeuroTechnologies), according to the instructions of the manufacturer. Spines were counted along dendrites starting from their point of origin from the primary dendrites (Zhang et al., 2014). Images captured using a microscope (BZ-X710, Keyence) were superimposed.

DNA methylation study. The purification of genomic DNA and sodium bisulfite conversion were performed as described previously (Mori et al., 2010). The converted DNA was purified and used as a template for PCR using epiTaq polymerase (TAKARA). Bisulfite-treated DNA was amplified for the sequence within promoter 4 of the $b d n f$ gene with specific primers (forward, 5' -TTT GTG TGT GTG AAT TTG TTA GGA TTG GAA GTG-3'; reverse, 5'-AGG GGA AAT ATA TAG TAA GAG TTT AGA ATT TTG G-3'), which were designed to cover the areas of interest with cytosine-phosphate-guanine $(\mathrm{CpG})$ sites. Amplification was performed under the following conditions: $2 \mathrm{~min}$ at $95^{\circ} \mathrm{C}, 45 \mathrm{~s}$ at $95^{\circ} \mathrm{C}, 1.5 \mathrm{~min}$ at $54^{\circ} \mathrm{C}$, and $1.5 \mathrm{~min}$ at $72^{\circ} \mathrm{C} \times 35$. PCR products were purified and cloned with the Mighty-TA Cloning Kit (TAKARA) for sequencing. Unmethylated cytosines appear as thymines, while methylated cytosines appear as cytosines. The efficiency of bisulfite conversion was confirmed by the rare presence of unconverted $\mathrm{C}$ residues in nonCpG regions.

Redox proteome analysis. After being perfused with HBSS containing $10 \mathrm{~mm} N$-ethylmaleimide, PFCs were extracted and homogenized in 50 $\mathrm{mm}$ Tris buffer, $\mathrm{pH} 8.5$, containing $8 \mathrm{~m}$ urea and 4\% CHAPS. Following the precipitation of proteins with acetone, protein aliquots of $100 \mu \mathrm{g}$ were reduced with TCEP [Tris(2-carboxyethyl)phosphine] at $37^{\circ} \mathrm{C}$ for $60 \mathrm{~min}$ and reacted with ICAT reagents (AB Sciex) according to the instructions of the manufacturer. Purified ICAT-labeled proteins were digested with trypsin. ICAT-labeled peptides separated by nano-HPLC were identified and quantified using the Orbitrap mass spectrometer.

Assessment of the redox state of NR1. Homogenates of PFC were reacted with EZ-Link Maleimide-PEG2-Biotin (ThermoFisher Scientific) to label the cysteine sulfhydryl groups of proteins. Following the extraction of biotinylated proteins with Zeba Spin Desalting Column (ThermoFisher Scientific), they were affinity purified with NeutrAvidin-agarose (ThermoFisher Scientific). Biotinylated proteins or cell lysates were separated by SDS-PAGE and transferred to PVDF membranes. The membranes were incubated overnight at $4^{\circ} \mathrm{C}$ with an anti-NR1 (1: 1000; catalog \#D65B7, Cell Signaling Technology; RRID:AB_ 1904067). After being washed, the membrane was incubated with HRP-conjugated secondary antibodies for $1 \mathrm{~h}$ at room temperature and subsequently with ImmunoStar LD (Wako). The density of the band was analyzed using ImageJ software.

Statistic analyses. Data are shown as the mean \pm SEM. Comparison of the two groups was performed using the unpaired Student's $t$ test. For comparison of more than two groups with comparable variances, oneway or two-way ANOVA was performed followed by Bonferroni's test to 
A

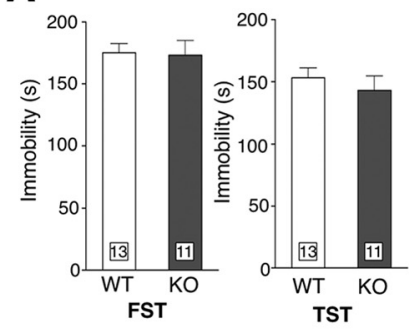

E

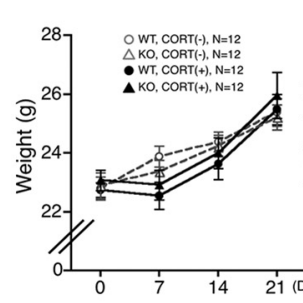

B

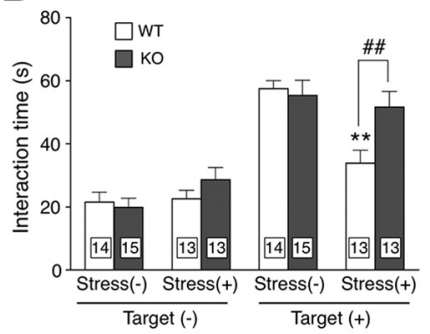

F
C
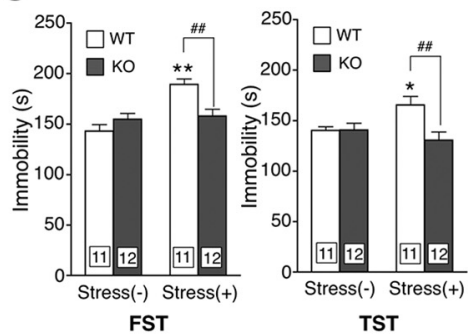

G
D

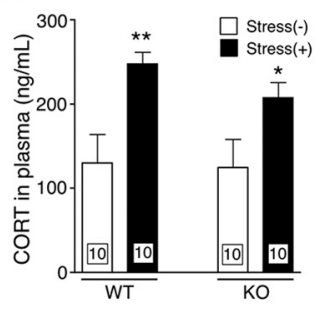

H
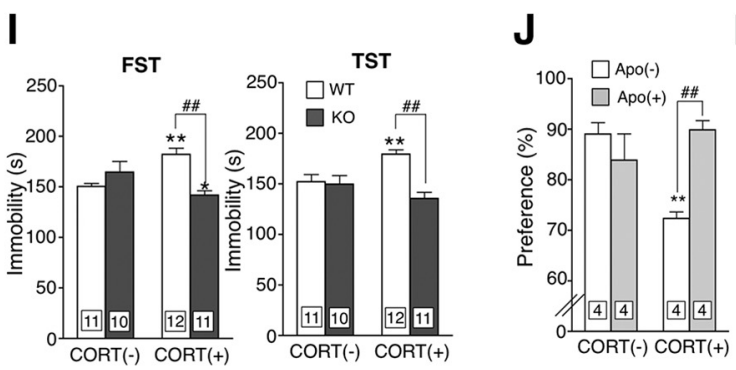

K
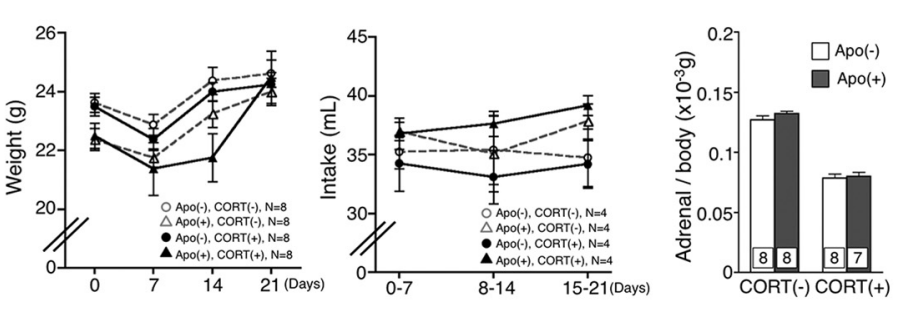

Figure 1. Nox1 deficiency abrogated depressive-like behaviors. A, Immobility time in the FST and TST. WT and K0 mice represent control littermates (WT mice) and Nox $1^{-/ Y}$ mice, respectively (FST: $t_{(22)}=0.087, p=0.931 ;$ TST: $t_{(22)}=0.801, p=0.432$, unpaired $t$ test). $\boldsymbol{B}$, Time spent in social interaction with the target mouse following chronic social defeat stress. ${ }^{* *} p<0.01$ compared with stress $(-) /$ target $(+)$; \#\# $<0.01$. C, Immobility time following chronic social defeat stress in the FST and in TST. ${ }^{* *} p<0.01,{ }^{*} p<0.05$ compared with stress $(-) /$ WT and \#\#p $<0.01$. $D$, Plasma CORT levels following chronic social defeat stress (WT: $t_{(18)}=3.212, p<0.01$; NOX1-KO: $t_{(18)}=2.159, p<0.05$, unpaired $t$ test). $E$, CORT-induced changes in body weight (left) and water intake (right). $\boldsymbol{F}$, Alterations in plasma CORT levels (left) and the weight of adrenal glands (right) following CORT administration. ${ }^{*} p<0.05$ compared with Day 0. G, Time spent in social interaction with the target mouse following the long-term administration of CORT. ${ }^{* *} p<0.01$ compared with stress $(-) / \operatorname{target}(+)$ and $\# p<0.05$. $\boldsymbol{H}$, Time dependency of sucrose preference following CORT. ${ }^{* *} p<0.01$ compared with WT/CORT(14D) and \#\#p $<0.01$. I, Immobility time following long-term administration of CORT in FST and TST. ${ }^{* *} p<0.01$, ${ }^{*} p<0.05$ compared with CORT( - ) and $\# \# p<0.01$. J, Effects of an antioxidant, Apo, on the preference for sucrose in mice administered CORT. ${ }^{* *} p<0.01$ compared with Apo $(-) /$ CORT( - ) and \#\#p $<0.01$. $K$, Effects of Apo on CORT-induced changes in body weight (left) and water intake (right). $L$, Effects of apocynin on CORT-induced changes in the weight of adrenal glands. Adrenal glands were dissected from mice administered apocynin.

evaluate pairwise group differences. A repeated-measures ANOVA with two factors was used for analysis of the body weight and water intake. ANOVA with three factors was used for the analysis of time dependency on sucrose preference. The correlation between two values was statistically analyzed using Pearson's correlation coefficient.

\section{Results}

Nox1 deficiency abrogated depressive-like behavior induced by chronic social defeat stress

Between naive WT and Nox $1^{-/ Y}$ mice, there was no difference in the immobility time in the FST and TST (Fig. 1A). Simultaneously, the time spent in social interaction with the target mouse was equivalent between naive WT and $N o x 1^{-/ Y}$ mice. When mice were subjected to chronic social defeat stress for 11 consecutive days, WT mice showed social avoidance, which was reflected by a decrease in the time spent interacting with the target mouse. In contrast, such depressive-like behavior was absent in $N o x 1^{-/ Y}$ mice (Fig. $1 B$; genotype $F_{(1,102)}=3.71, p=0.057$; treatment $F_{(3,102)}=40.44, p<0.01$; interaction $\left.F_{(3,102)}=3.12, p<0.05\right)$. Similarly, WT mice subjected to chronic stress demonstrated increased immobility in FST and TST, while no change was observed in $N o x 1^{-/ Y}$ mice (Fig. 1C; FST: genotype $F_{(1,42)}=2.537$, $p=0.119$; stress $F_{(1,42)}=15.58, p<0.01$; interaction
$F_{(1,42)}=12.13, p<0.01$; TST: genotype $F_{(1,42)}=5.64, p<0.05$; stress $F_{(1,42)}=1.05, p=0.312$; interaction $F_{(1,42)}=5.85, p<$ $0.05)$. As shown in Figure $1 D$, chronic stress increased the levels of plasma CORT in both genotypes, as reported previously (Lehmann et al., 2013).

Nox1 deficiency abrogated depressive-like behaviors induced by long-term administration of CORT

The long-term administration of CORT (35 $\mu \mathrm{g} / \mathrm{ml}$ in drinking water) disrupts the hypothalamus-pituitary-adrenal system in mice, leading to continuously high levels of plasma CORT at $7 \mathrm{~d}$, and the levels are maintained at $21 \mathrm{~d}$ after administration (Johnson et al., 2006). During the long-term administration of CORT, there was no difference between the genotypes in body weight gain (Fig. 1E; genotype: $F_{(1,11)}=0.01, p=0.928$; CORT level: $F_{(1,11)}=1.64, p=0.226$; day: $F_{(3,33)}=77.90, p<0.01$; genotype $\times$ CORT: $F_{(1,11)}=0.73, p=0.413$; CORT $\times$ day: $F_{(3,33)}=$ $14.12, p<0.01$; genotype $\times$ day: $\left.F_{(3,33)}=0.62, p=0.606\right)$, volume of water intake (Fig. $1 E$; genotype: $F_{(1,5)}=0.15, p=$ 0.715; CORT: $F_{(1,5)}=1.07, p=0.350$; day: $F_{(2,10)}=4.53, p<$ 0.05; genotype $\times$ CORT: $F_{(1,5)}=0.64, p=0.459$; CORT $\times$ day: $F_{(2,10)}=19.70, p<0.01$; genotype $\times$ day: $\left.F_{(2,10)}=2.13, p=0.169\right)$, 
A
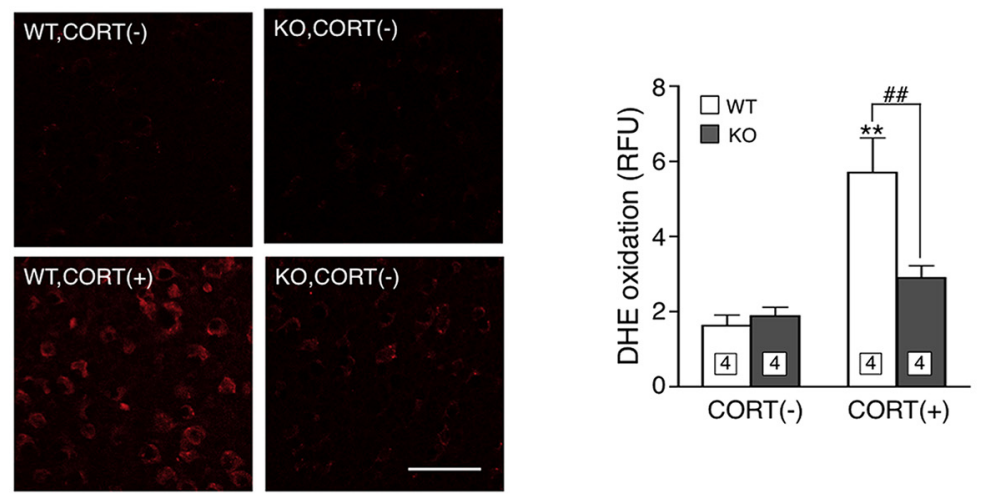

B

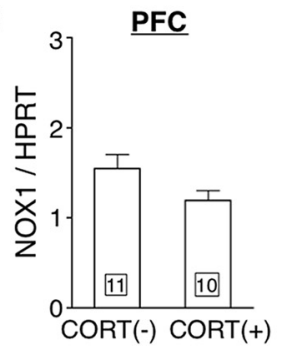

C

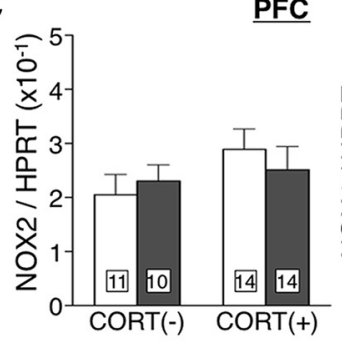

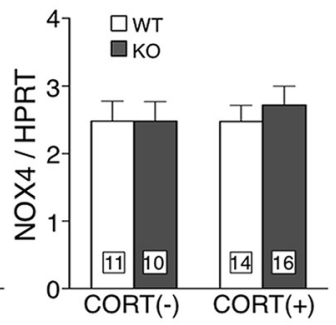

D

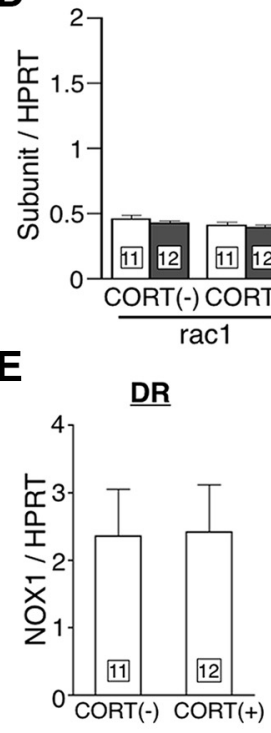

F

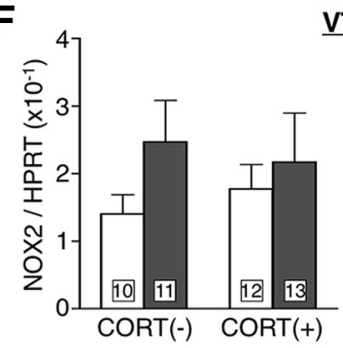

PFC

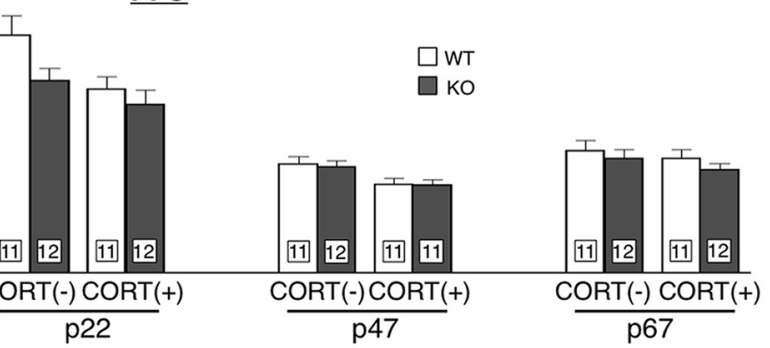

IH

VTA

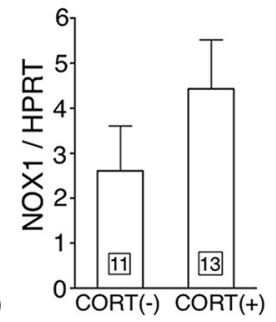

VTA

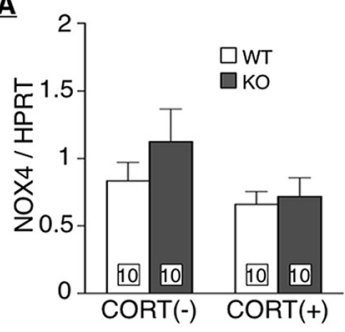

G
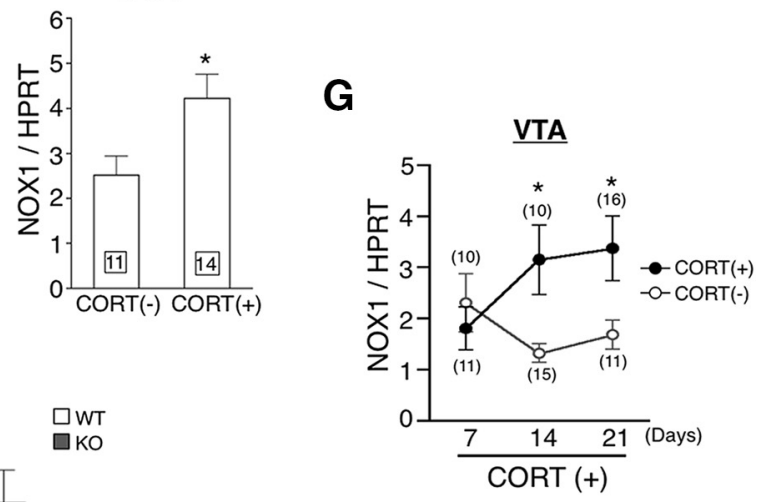

Figure 2. CORT increased ROS production and upregulated NOX1 in different brain regions. A, ROS production in PFC assessed by DHE fluorescence following $21 \mathrm{~d}$ of CORT administration. Left panels demonstrate representative photomicrographs of the fluorescence of DHE oxidation in PFC. Scale bar, $50 \mu \mathrm{m}$. The right panel demonstrates quantitative analysis of fluorescence in PFC. ${ }^{* *} p<$ 0.01 compared with WT/CORT $(-)$ and \#\#p $<0.01$. B, NOX1 mRNA levels in PFC following CORT administration ( $t_{(19)}=1.187, p=0.166$ by unpaired $t$ test). C, Levels of NOX2 and NOX4 mRNAs in PFC of mice following CORT administration. $\boldsymbol{D}$, The mRNA levels of other subunits of NADPH oxidase in PFC of mice following CORT administration. $E$, NOX1 mRNA levels in various brain regions of mice following CORT administration (dorsal raphe: $t_{(22)}=0.066, p=0.948$; thalamus: $t_{(21)}=1.212, p=0.239$; ventral tegmental area: $t_{(17)}=2.545,{ }^{*} p<0.05$ compared with CORT( - ) by unpaired $t$ test). DR, Dorsal raphe; TH, thalamus. $F$, Levels of NOX2 and NOX4 mRNAs in VTA of mice following CORT administration. G, Time dependency of NOX1 mRNA expression in VTA. ${ }^{*} p<0.05$ compared with WT/CORT(-). 
and the level of plasma CORT or a compensatory decline in the weight of adrenal glands (Fig. $1 F$; CORT level: genotype: $F_{(2,22)}=$ $0.09, p=0.764$; day: $F_{(2,22)}=9.17, p<0.01$; interaction: $F_{(2,22)}=$ $0.06, p=0.944$; weight of adrenal gland: genotype: $F_{(1,43)}=2.30$, $p=0.137$; CORT: $F_{(1,43)}=163.53, p<0.01$; interaction: $F_{(1,43)}=$ $2.30, p=0.1371)$. On the other hand, the administration of CORT markedly attenuated the time spent for social interaction in WT mice, but not in $\operatorname{Noxl}^{-/ Y}$ mice (Fig. 1G; genotype: $F_{(1,88)}=$ $1.23, p=0.270$; treatment: $F_{(3,88)}=44.30, p<0.05$; interaction: $\left.F_{(3,88)}=3.65, p<0.05\right)$. Concomitantly, a decreased preference for sucrose, which is indicative of anhedonia, was observed in WT mice administered CORT for $21 \mathrm{~d}$ but not in Nox1 ${ }^{-/ Y}$ mice (Fig. $1 \mathrm{H}$; genotype: $F_{(1,49)}=0.70, p=0.408$; CORT: $F_{(1,49)}=0.65, p=$ 0.424 ; day: $F_{(1,49)}=0.07, p=0.800$; genotype $\times$ CORT: $F_{(1,49)}=$ $3.35, p=0.074$; CORT $\times$ day: $F_{(1,49)}=3.02, p=0.089$; genotype $\times$ day: $\left.F_{(1,49)}=6.72, p<0.05\right)$. As shown in Figure 1I, WT mice administered CORT demonstrated increased immobility in FST and TST, while no change was observed in $N_{0 x 1^{-/ Y}}$ mice (FST: genotype: $F_{(1,39)}=4.63, p<0.05$; CORT: $F_{(1,39)}=0.54, p=$ 0.465 ; interaction: $F_{(1,39)}=19.51, p<0.01$; TST: genotype: $F_{(1,39)}$ $=12.39, p<0.01$; CORT: $F_{(1,39)}=1.05, p=0.313$; interaction: $\left.F_{(1,39)}=9.96, p<0.01\right)$. Coadministration of the antioxidant apocynin with CORT prevented the decrease in the preference for sucrose (Fig. 1J; Apo: $F_{(1,12)}=3.97, p=0.070$; CORT: $F_{(1,12)}=$ 2.97, $p=0.110$; interaction: $\left.F_{(1,12)}=13.38, p<0.01\right)$, While administration of apocynin affected the pattern of body weight gain (Fig. $1 K$; Apo $F_{(1,7)}=6.15, p<0.05$; $\operatorname{CORT~} F_{(1,7)}=1.40, p=$ 0.276 ; day $F_{(3,21)}=83.12, p<0.01 ;$ Apo $\times$ CORT: $F_{(1,7)}=0.00$, $p=0.975$; CORT $\times$ day: $F_{(3,21)}=5.80, p<0.01$; Apo $\times$ day: $\left.F_{(3,21)}=8.99, p<0.01\right)$ and of water intake during the time course (Fig. $1 K$; Apo: $F_{(1,3)}=1.52, p=0.31$; CORT: $F_{(1,3)}=0.00$, $p=0.984$; day: $F_{(2,6)}=2.17, p=0.196$; Apo $\times$ CORT: $F_{(1,3)}=$ 6.11, $p=0.090$; CORT $\times$ day: $F_{(2,6)}=0.37, p=0.708$; Apo $\times$ day: $\left.F_{(2,6)}=10.19, p<0.05\right)$, it did not affect the weight of the adrenal glands (Fig. $1 L$; Apo: $F_{(1,27)}=1.12, p=0.300$; CORT: $F_{(1,27)}=246.19, p<0.01$; interaction: $\left.F_{(1,27)}=0.34, p=0.565\right)$.

\section{CORT increased ROS production and upregulated NOX1 in different brain regions}

Next, we investigated ROS production and the expression of NOX1 in brain areas responsible for emotional behaviors. When we measured ROS levels in cell homogenate of the amygdala, hippocampus, hypothalamus, nucleus accumbens (NAcc) and PFC by L-012 chemiluminescence, the administration of CORT significantly increased ROS production in PFC of WT mice but not of $\mathrm{Noxl}^{-/ \mathrm{Y}}$ mice (data not shown). When ROS production in the PFC was examined by DHE staining, the fluorescence in Nox1 ${ }^{-/ Y}$ mice was less intense compared with that in WT mice (Fig. $2 A$; genotype: $F_{(1,12)}=5.81, p<0.05$; CORT: $F_{(1,12)}=$ 23.19, $p<0.01$; interaction: $\left.F_{(1,12)}=8.34, p<0.05\right)$. On the other hand, CORT did not affect the expression of NOX1 mRNA in PFC (Fig. 2B). The expression of NOX2, NOX4, or any of the regulatory subunits of NADPH oxidase was not upregulated in PFC by CORT administration. Indeed, CORT administration decreased the expression of $\mathrm{p} 22^{\text {phox }}$ and $\mathrm{p} 47^{\text {phox }}$ (Fig. $2 C, D$; NOX2: genotype: $F_{(1,45)}=0.03, p=0.873$; CORT: $F_{(1,45)}=1.78, p=$ 0.189 ; interaction: $F_{(1,45)}=0.66, p=0.421$; NOX4: genotype: $F_{(1,47)}=0.19, p=0.667$; CORT: $F_{(1,47)}=0.17, p=0.683$; interaction: $F_{(1,47)}=0.19, p=0.189$; rac1: genotype: $F_{(1,42)}=0.98$, $p=0.327$; CORT: $F_{(1,42)}=2.25, p=0.141$; interaction: $F_{(1,42)}=$ $0.05, p=0.823$; p22 $2^{\text {phox }}$ : genotype: $F_{(1,42)}=4.27, p<0.05$; CORT: $F_{(1,42)}=6.99, p<0.05$; interaction: $F_{(1,42)}=1.04, p=$ $0.314 ; \mathrm{p}^{4} 7^{\text {hox }}$ : genotype: $F_{(1,41)}=0.07, p=0.786 ;$ CORT: $F_{(1,41)}=$
7.88, $p<0.01$; interaction: $F_{(1,41)}=0.02, p=0.887 ; \mathrm{p} 67^{\text {phox }}$ : genotype: $F_{(1,42)}=1.32, p=0.258$; CORT: $F_{(1,42)}=1.17, p=$ 0.285 ; interaction: $\left.F_{(1,42)}=0.04, p=0.851\right)$. PFC receives projections from areas such as the dorsal raphe, thalamus, and VTA. Among these regions, the expression of NOX1 mRNA, but not of NOX2 or NOX4, was significantly increased only in VTA (Fig. $2 E, F ;$ NOX2: genotype: $F_{(1,42)}=1.71, p=0.198 ; \mathrm{CORT}: F_{(1,42)}=$ $0.00, p=0.953$; interaction: $F_{(1,42)}=0.35, p=0.555$; NOX4: genotype: $F_{(1,36)}=1.17, p=0.287$; CORT: $F_{(1,36)}=3.25, p=$ 0.08 ; interaction: $\left.F_{(1,36)}=0.51, p=0.481\right)$. The induction of NOX1 mRNA was identified at $14 \mathrm{~d}$ after CORT administration, which preceded the appearance of depressive-like behaviors (Fig. $2 G$; day: $F_{(1,37)}=0.45, p=0.637$; CORT: $F_{(1,37)}=6.10, p<0.05$; interaction: $\left.F_{(1,37)}=3.20, p<0.05\right)$.

To clarify the link between the level of NOX1 mRNA in VTA and depressive-like behaviors, gene silencing of NOX1 was performed using AAV2/rh10 expressing miRNA targeting NOX1 mRNA (Fig. $3 A$ ). As shown in Figure $3 B$, in WT mice injected with AAV2/rh10 to VTA, there were inverse correlations between (1) the level of NOX1 mRNA in VTA and sucrose preference as well as (2) ROS production in PFC and sucrose preference. In line with these findings, a positive correlation between the level of NOX1 mRNA in VTA and ROS production in PFC was demonstrated (Fig. 3B). On the other hand, no correlation was observed between the level of NOX1 mRNA in PFC and sucrose preference in WT mice injected with AAV2/rh10 to PFC (Fig. 3C). These findings support a causal link between NOX1 in VTA and depressive-like behaviors.

\section{CORT-induced downregulation of BDNF was NOX1 dependent}

Decreased expression of BDNF in the limbic area has been implicated in the etiology of MDD as well as in depressive-like behaviors in animals exposed to chronic stress (Tsankova et al., 2006; Thompson Ray et al., 2011). The expression of BDNF mRNA in PFC of WT mice, but not of Nox1 $1^{-/ Y}$ mice, was significantly decreased in mice administered CORT (Fig. 4A; genotype: $F_{(1,50)}=$ 2.17, $p=0.147$; CORT: $F_{(1,50)}=16.54, p<0.01$; interaction: $\left.F_{(1,50)}=4.70, p<0.05\right)$. Among several transcripts containing different 5 ' noncoding exons, the transcript containing exon IV of the $b d n f$ gene was similarly decreased in WT mice administered CORT but not in $\mathrm{Nox1}^{-/ Y}$ mice (Fig. 4A; genotype: $F_{(1,50)}=7.18$, $p<0.05$; CORT: $F_{(1,50)}=13.14, p<0.01$; interaction: $F_{(1,50)}=$ $5.18, p<0.05)$. On the other hand, the expression of BDNF mRNA in NAcc innervated by dopaminergic neurons from VTA did not alter in mice administered CORT (Fig. 4A; genotype: $F_{(1,42)}=0.82, p=0.371$; CORT: $F_{(1,42)}=0.10, p=0.755$; interaction: $\left.F_{(1,42)}=0.81, p=0.373\right)$.

As shown in Figure $4, B$ and $C$, the levels of BDNF mRNA were negatively correlated with the levels of NOX1 mRNA in VTA injected with AAV2/rh10, but not in PFC injected with AAV2/ rh10. Previous studies documented that prolonged stress or corticosterone administration alters the dendritic morphology of neurons in PFC (Cook and Wellman, 2004; Radley et al., 2006). Consistent with the downregulation of BDNF by the administration of CORT, the number of spines of apical dendrites of layer $\mathrm{V}$ pyramidal neurons was significantly reduced in PFC of WT mice but not of $\operatorname{Nox}^{-/ Y}$ mice (Fig. $4 D$, left; genotype: $F_{(1,52)}=5.64$, $p<0.05$; CORT: $F_{(1,52)}=6.34, p<0.05$; interaction: $F_{(1,52)}=$ $4.24, p<0.05)$. Although more apparent in WT mice, the decrease in spines of layer II/III was observed in both genotypes (Fig. $4 D$, middle; genotype: $F_{(1,50)}=0.65, p=0.424$; CORT: $F_{(1,50)}=26.10, p<0.01$; interaction: $\left.F_{(1,50)}=4.92, p<0.05\right)$. 
A
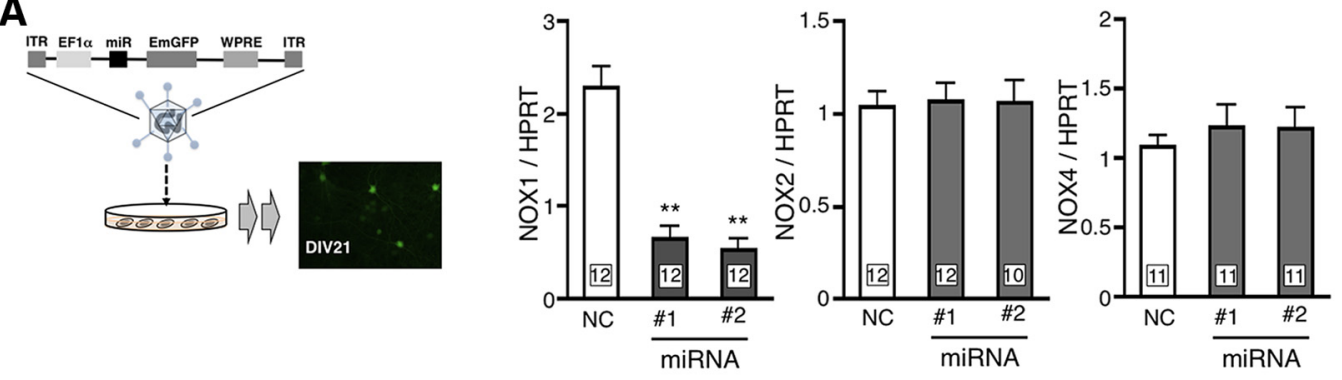

B
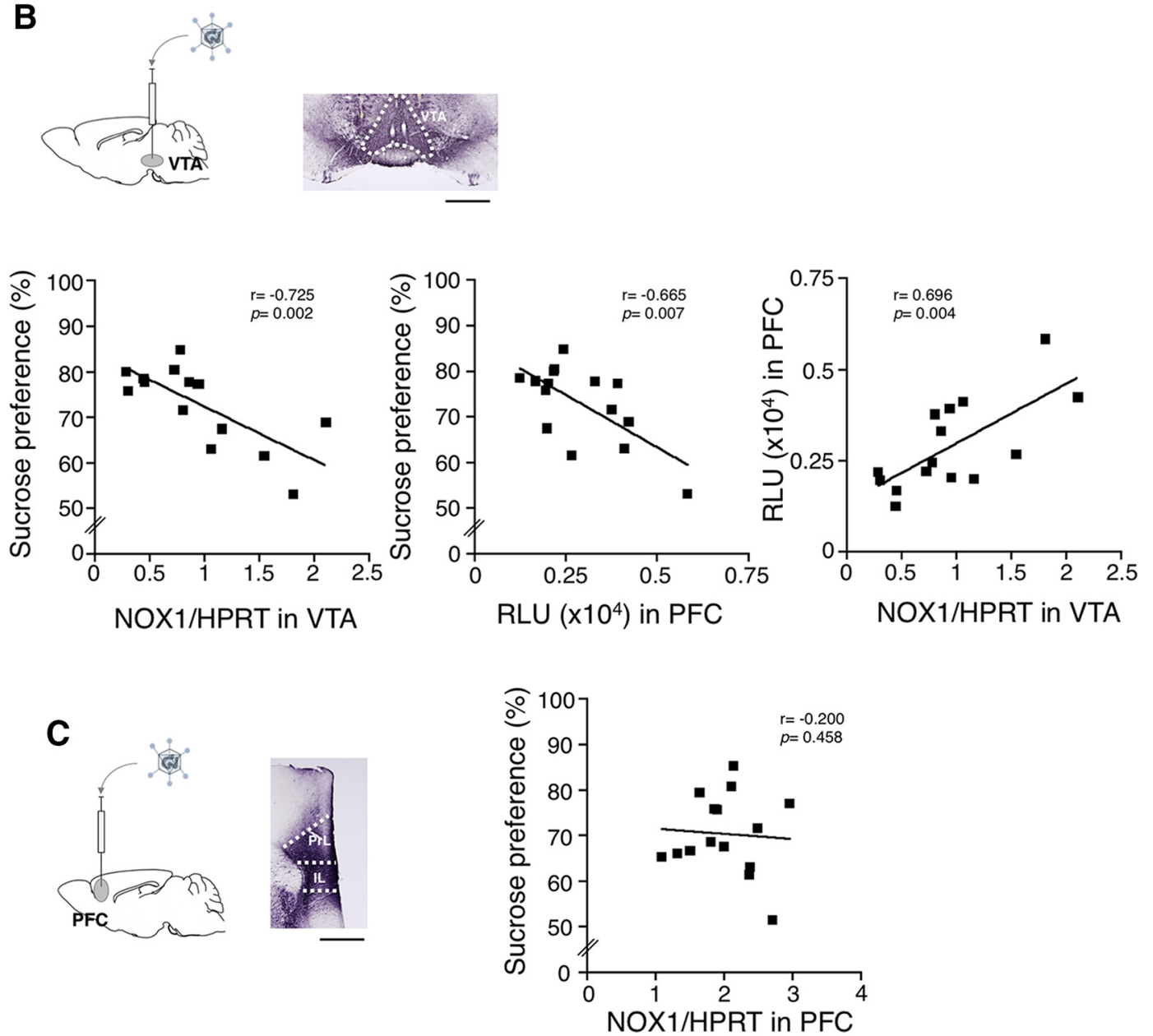

Figure 3. Increased NOX1 expression in VTA correlates with depressive-like behavior. A, Schematic diagram of gene silencing of NOX1 in primary cortical neurons using AAV2/rh10 coding miRNA against NOX1. The top demonstrates the structure of AAV-expressing cassettes harboring the artificial miRNA sequence and EmGFP. To verify the effects of miRNA on NOX1 expression, cultured embryonic neurons were infected with AAV2/rh10 expressing miRNA against NOX1 at DIV2. The total RNA in cultures was isolated at DIV21 when the fluorescence of GFP could be detected. Right panels indicate levels of NOX1, NOX2, and NOX4 mRNAs in cultured neurons transduced with AAV2/rh10 expressing the negative control (NC) or miRNAs against NOX1 (NOX1: $F_{(2,33)}=37.66, p<$ 0.01 , Bonferroni's post hoc test following one-way ANOVA; ** $p<0.01$ compared with NC; NOX2: $F_{(2,31)}=0.02, p=0.978 ;$ NOX4: $\left.F_{(2,30)}=0.31, p=0.736\right)$. B , Correlations between sucrose preference and the level of NOX1 mRNA in VTA (left) or superoxide production in PFC (middle) of mice transduced on injection of AAV2/rh10 into VTA. Schematic diagram and a representative photomicrograph of GFPs expressed in VTA are shown. The right panel represents the correlation between superoxide production in PFC and the level of NOX1 mRNA in VTA. Mice were administered CORT for $21 \mathrm{~d}$ starting 3 weeks after viral injection. Values were obtained from 15 animals. Immunohistochemistry was performed at 6 weeks after virus injection. Scale bar, $500 \mu \mathrm{m}$. C, No correlation between sucrose preference and the level of NOX1 mRNA in PFC of mice transduced with AAV2/rh10 into PFC. Values were obtained from 16 animals. Scale bar, $500 \mu \mathrm{m}$. PrL, Prelimbic; IL, infralimbic.

While CORT significantly decreased the number of spines in NAcc as reported previously (Morales-Medina et al., 2009), there was no difference between genotypes (Fig. $4 D$, right; genotype: $F_{(1,44)}=0.01, p=0.928$; CORT: $F_{(1,44)}=16.70, p<0.01$; interaction: $\left.F_{(1,44)}=0.94, p=0.339\right)$. These findings suggest that NOX1-mediated morphological changes in layer V of PFC may primarily contribute to depressive-like behaviors.

\section{CORT-induced DNA methylation in the $b d n f$ gene was NOX1 dependent}

Previously, DNA methylation in the promoter of $b d n f$ exon IV was reported to affect the neuronal activity-dependent BDNF expression in mice (Martinowich et al., 2003). We therefore assessed the relevance of NOX1 in DNA methylation of the promoter region (P4) of exon IV in the $b d n f$ gene. Sequencing 
A

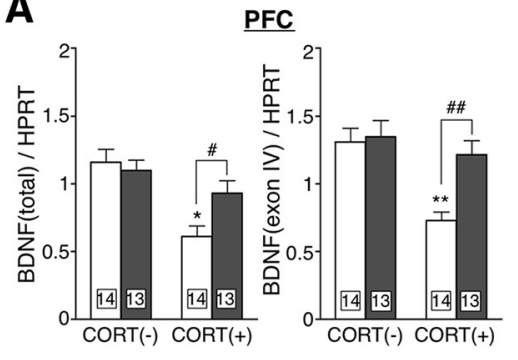

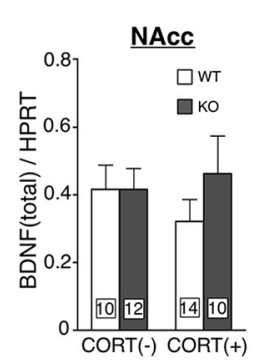

ORT(-) CORT(+)

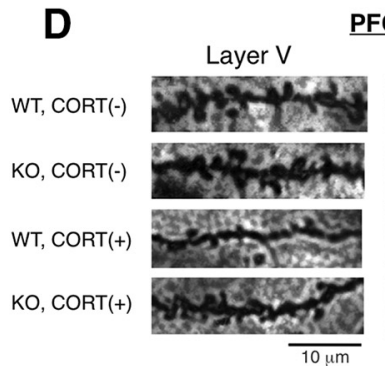

PFC
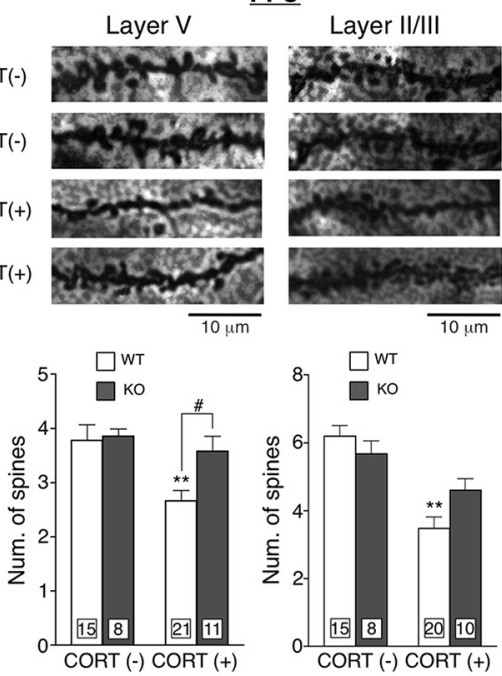
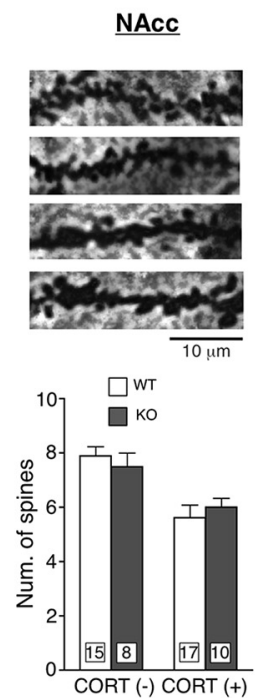

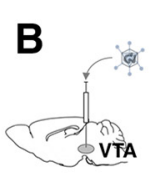

C
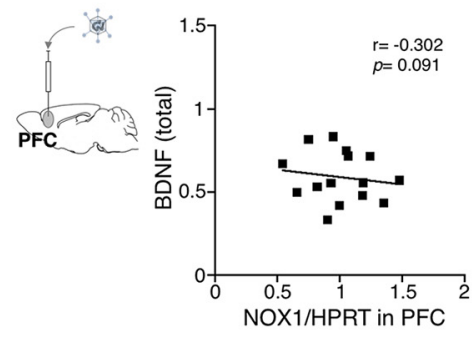

E

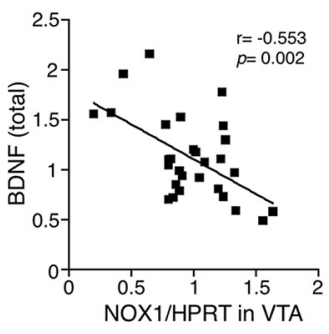

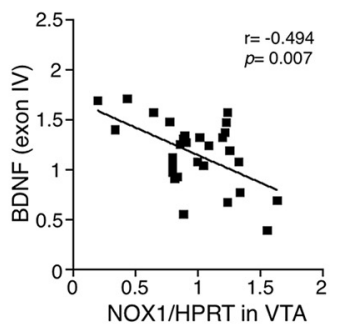

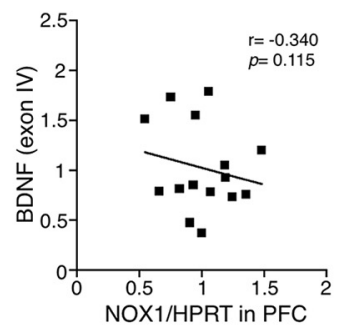

NOX1/HPRT in PFC

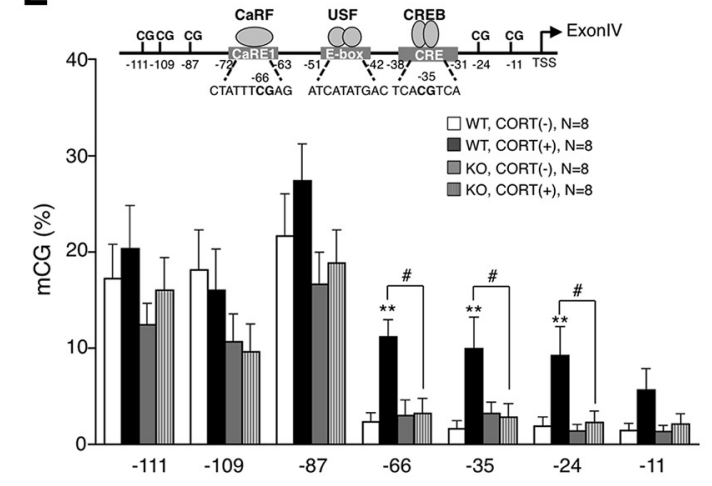

Figure 4. CORT-induced downregulation of BDNF and DNA methylation in the $b d n f$ gene were NOX1 dependent. $A$, Transcript levels of total BDNF and exon IV of the $b d n f$ gene in PFC or NAcc following the long-term administration of CORT. ${ }^{* *} p<0.01,{ }^{*} p<0.05$ compared with WT/CORT( -$)$. $B$, Correlations between the levels of BDNF mRNA in PFC and N0X1 mRNA in VTA of mice transduced with AAV2/rh10 into VTA. Values were obtained from 29 animals administered CORT. C, No correlation between the levels of BDNF mRNA in PFC and NOX1 mRNA in PFC of mice transduced with AAV2/rh10 into PFC. Values were obtained from 16 animals administered CORT. $\boldsymbol{D}$, Number of spines following the long-term administration of CORT. Representative photomicrographs of spines in PFC and NAcc (top). ${ }^{* *} p<0.01$ compared with WT/CORT( - ) and \#p $<0.05$. $\boldsymbol{E}$, A schematic diagram of regulatory elements in the promoter region of exon IV of the mouse $b d n f$ gene (top) and methylation of $\mathrm{CpG}$ sites in the promoter depicted by bisulfate sequencing analyses (bottom). The position of the transcriptional start site (TSS) is set at zero. Values were obtained from eight animals per each group in two independent experiments. ${ }^{* *} p<0.01$ compared with WT/CORT $(-)$ and \#p $<0.05$.

analyses of the PCR products of bisulfite-converted DNA demonstrated that the methylation of specific CpG sites was significantly increased in WT mice administered CORT for $21 \mathrm{~d}$. In contrast, methylation of these sites in $N o x 1^{-/ Y}$ remained unchanged following CORT administration (Fig. $4 E$; $\mathrm{CpG}$ at -11 bp: genotype: $F_{(1,28)}=1.92, p=0.177$; CORT: $F_{(1,28)}=3.39, p=$ 0.076 ; interaction: $F_{(1,28)}=1.61, p=0.216$; $\mathrm{CpG}$ at $-24 \mathrm{bp}$ : genotype: $F_{(1,28)}=4.77, p<0.05$; CORT: $F_{(1,28)}=5.86, p<0.05$; interaction: $F_{(1,28)}=3.60, p=0.068$; CpG at -35 bp: genotype: $F_{(1,28)}=2.12, p=0.157$; CORT: $F_{(1,28)}=4.37, p<0.05$; interaction: $F_{(1,28)}=5.31, p<0.05$; CpG at -66 bp: genotype: $F_{(1,28)}=$ 6.00, $p<0.05$; CORT: $F_{(1,28)}=9.10, p<0.01$; interaction: $F_{(1,28)}=8.42, p<0.01 ; \mathrm{CpG}$ at -87 bp: genotype: $F_{(1,28)}=3.30$, $p=0.080$; CORT: $F_{(1,28)}=1.13, p=0.298$; interaction: $F_{(1,28)}=$ $0.22, p=0.643$; CpG at -109 bp: genotype: $F_{(1,28)}=3.72, p=$ 0.064 ; CORT: $F_{(1,28)}=0.19, p=0.665$; interaction: $F_{(1,28)}=0.02$, $p=0.890$; $\mathrm{CpG}$ at -111 bp: genotype: $F_{(1,28)}=1.69, p=0.205$; CORT: $F_{(1,28)}=0.90, p=0.350$; interaction: $F_{(1,28)}=0.00, p=$ 0.946). These findings further support a causal link between NOX1 and the downregulation of BDNF induced by CORT.
NR1 was the target molecule of NOX1-derived ROS in PFC Next, we investigated the target molecules of NOX1-derived ROS associated with the downregulation of BDNF and depressive-like behaviors. A redox proteomics approach was used to identify proteins in PFC that underwent oxidative modification of cysteine residues following CORT treatment. In total, 313 proteins containing oxidized cysteine residues were detected in PFC of control mice without CORT treatment. Upon the administration of CORT, 225 proteins with oxidized cysteine residues were detected in both genotypes, among which 42 proteins in WT mice underwent increased oxidative modification compared with $N o x 1^{-/ Y}$ mice. By compiling the data from the animal groups with or without CORT treatment, 16 proteins were noted to contain NOX1-sensitive cysteine residues (Table 1). NR1, NR2B, and NSF were among these proteins. When we examined mRNA levels of these three molecules, no alteration was demonstrated in mice treated with CORT (Fig. $5 A$; NR1: genotype: $F_{(1,36)}=0.11$, $p=0.738$; CORT: $F_{(1,36)}=2.09, p=0.157$; interaction: $F_{(1,36)}=$ $0.03, p=0.853$; NR2B: genotype: $F_{(1,36)}=0.01, p=0.933$; CORT: $F_{(1,36)}=0.41, p=0.524$; interaction: $F_{(1,36)}=0.01, p=0.942$; NSF: genotype: $F_{(1,36)}=1.96, p=0.170$; CORT: $F_{(1,36)}=0.00$, 
Table 1. Identity of peptides showing a genotype-specific increase in oxidized cysteine following CORT treatment

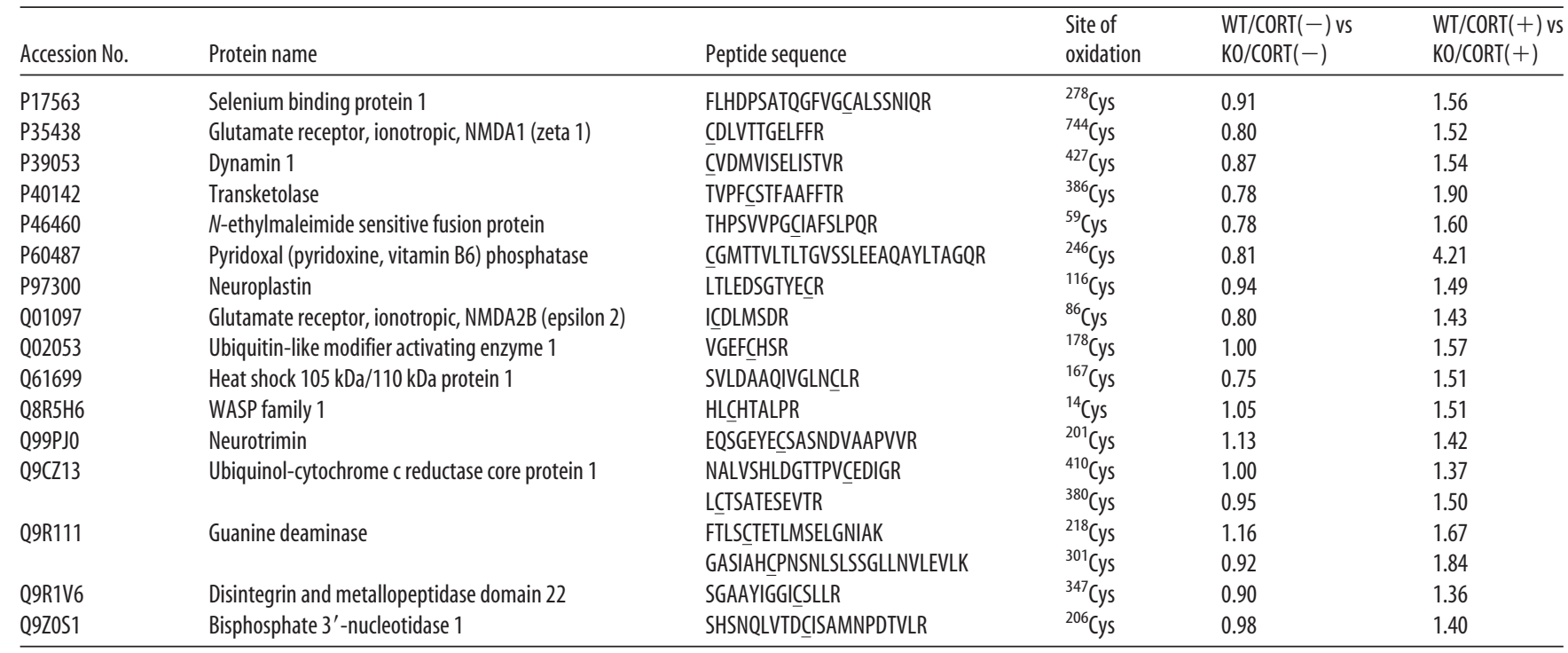

Peptides with an ion score of $>20$ were retrieved. These peptides are listed on the basis of a difference of $>1.30$ in the ratio between WT/CORT $(+)$ and KO/CORT $(+)$ and within $0.75-1.25$ in the ratio between WT/CORT $(-)$ and KO/CORT(-). Underlining indicates Cys.

$p=0.998$; interaction: $\left.F_{(1,36)}=0.01, p=0.930\right)$. These findings indicated that the increased oxidization of these proteins was not due to the upregulation of proteins induced by CORT.

We then focused our study on NR1 because redox proteome analyses revealed the NOX1-dependent oxidization of Cys744 of NR1, which was reported to play a critical role in the redoxsensitive modulation of NMDA receptor activity (Sullivan et al., 1994). When the redox state of NR1 was examined by the biotin pull-down assay, lower levels of free sulfhydryl $(-\mathrm{SH})$ groups in NR1 were demonstrated in PFC of CORT-treated WT mice compared with $N o x 1^{-/ Y}$ mice (Fig. $5 B$; genotype: $F_{(1,32)}=11.21, p<$ 0.01 ; CORT: $F_{(1,32)}=1.01, p=0.323$; interaction: $F_{(1,32)}=10.51$, $p<0.01)$.

To verify the importance of the oxidation of Cys744 in NR1, isolated cortical neurons were infected with lentivirus encoding NR1 or mutant NR1 replacing Cys744 with Ala. As shown in Figure $5 C$, a significant increase in exon IV-containing BDNF transcripts was demonstrated in NR1-infected neurons exposed to NMDA. In the presence of $\mathrm{H}_{2} \mathrm{O}_{2}$, the NMDA-induced upregulation of BDNF mRNA was significantly suppressed. In neurons harboring mutant NR1 (C744A), however, the levels of BDNF mRNA were well maintained (construct: $F_{(2,48)}=5.45, p<0.05$; treatment: $F_{(2,48)}=35.67, p<0.01$; interaction: $F_{(2,48)}=4.96$, $p<0.05)$. Accordingly, NR1 was depicted as a target molecule modified by ROS to regulate the expression of BDNF mRNA in cortical neurons.

\section{Discussion}

The present findings clearly indicated a causal link between NOX1 in the mesocortical pathway and depressive-like behaviors. In a CORT-treated mouse model, reduced BDNF expression was attributed to NOX1-dependent DNA methylation in PFC. Subsequent redox proteome analyses revealed NR1 as one of the target molecules of NOX1-derived ROS. In fact, the NMDAinduced increase in BDNF mRNA was unaffected by ROS in cortical neurons expressing mutant NR1 (C744A) insensitive to oxidative modification. These findings support the idea that NOX1-derived ROS oxidize NR1 and attenuate NMDA receptor activity, leading to the downregulation of BDNF expression to elicit depressive-like behaviors.
A significant decrease in the number of spines in PFC was suppressed in mice deficient in Nox1. Repeated stress is known to alter the dendritic morphology in the medial PFC (Radley et al., 2006), and such anatomical abnormalities were associated with concomitant behavioral deficits (Liston et al., 2006; Dias-Ferreira et al., 2009). In patients experiencing depression, the neuronal activity in PFC is reduced (Kang et al., 2012), which is consistent with the atrophy of PFC neurons reported in the animal model. The present findings provide evidence that prefrontal dendritic remodeling is mediated by NOX1 and takes part in stress-related impairments symptomatic of depressive disorders.

Oxidative stress has been implicated in the pathogenesis of MDD (Ng et al., 2008). The increased production of ROS in PFC has been demonstrated in an animal model of depression induced by the long-term administration of CORT (Gupta et al., 2015). In the hippocampus of mice following restraint stress, on the other hand, an increased level of ROS was reported, which was accompanied by the upregulation of regulatory subunits of NADPH oxidase, $\mathrm{p} 47^{\text {phox }}$, and $\mathrm{p} 67^{\text {phox }}$ (Seo et al., 2012). Yet, in our study, the generation of ROS in the hippocampus was unchanged, and there was a decrease in the level of $\mathrm{p} 47^{\text {phox }} \mathrm{mRNA}$ in PFC. This discrepancy may be due to the different stress models applied in the experiments. In our models, a sustained increase in plasma CORT levels was demonstrated in mice that had been subjected to social defeat stress or had received CORT. On the other hand, an increase in plasma CORT levels following restraint stress was reported to be transient (Kim and Han, 2006).

Given that CORT increases ROS in PFC and upregulates NOX1 mRNA in VTA, the mesocortical projection appears to mediate NOX1-dependent depressive-like behaviors. In fact, the selective knockdown of NOX1 in VTA ameliorated CORTinduced depressive-like behaviors. VTA is made up of a mixture of dopaminergic, GABAergic, and glutamatergic neurons, which project to other brain regions such as PFC, NAcc, hypothalamus, and amygdala. In this study, ROS production was increased only in PFC among these brain regions of mice treated with CORT. Although there is no assurance that changes in NOX1 mRNA expression in VTA correspond to changes in NOX1 enzyme activity, a significant difference in ROS production in PFC was 
A

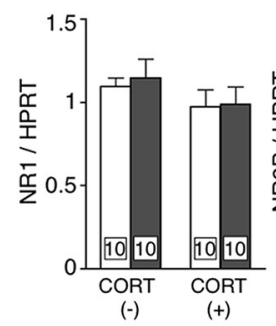

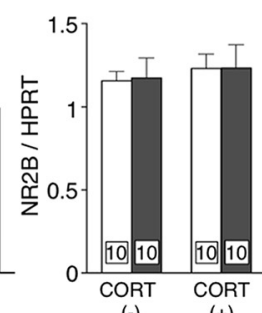

$(-) \quad(+)$

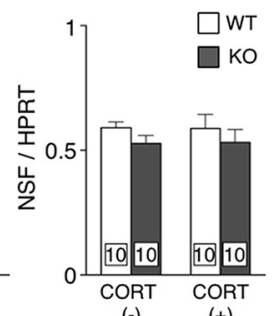

$(-) \quad(+)$

B
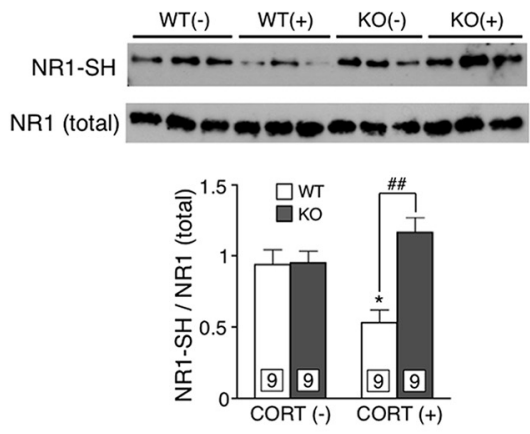

C
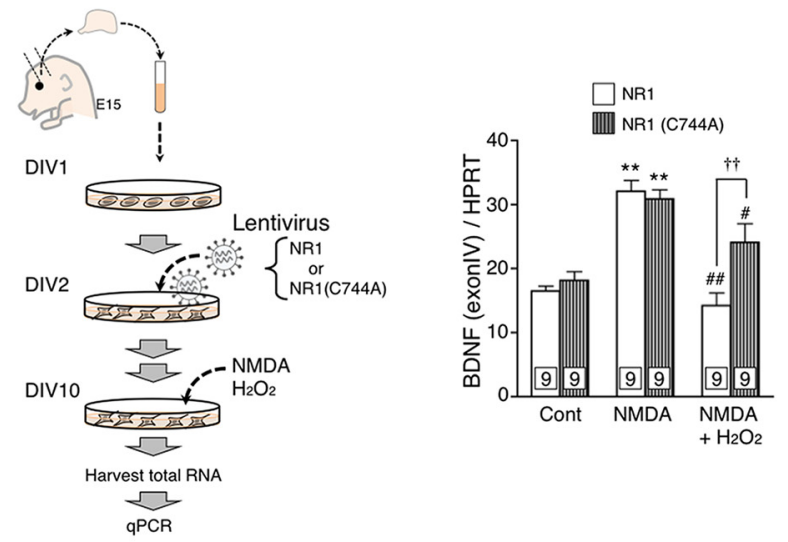

D
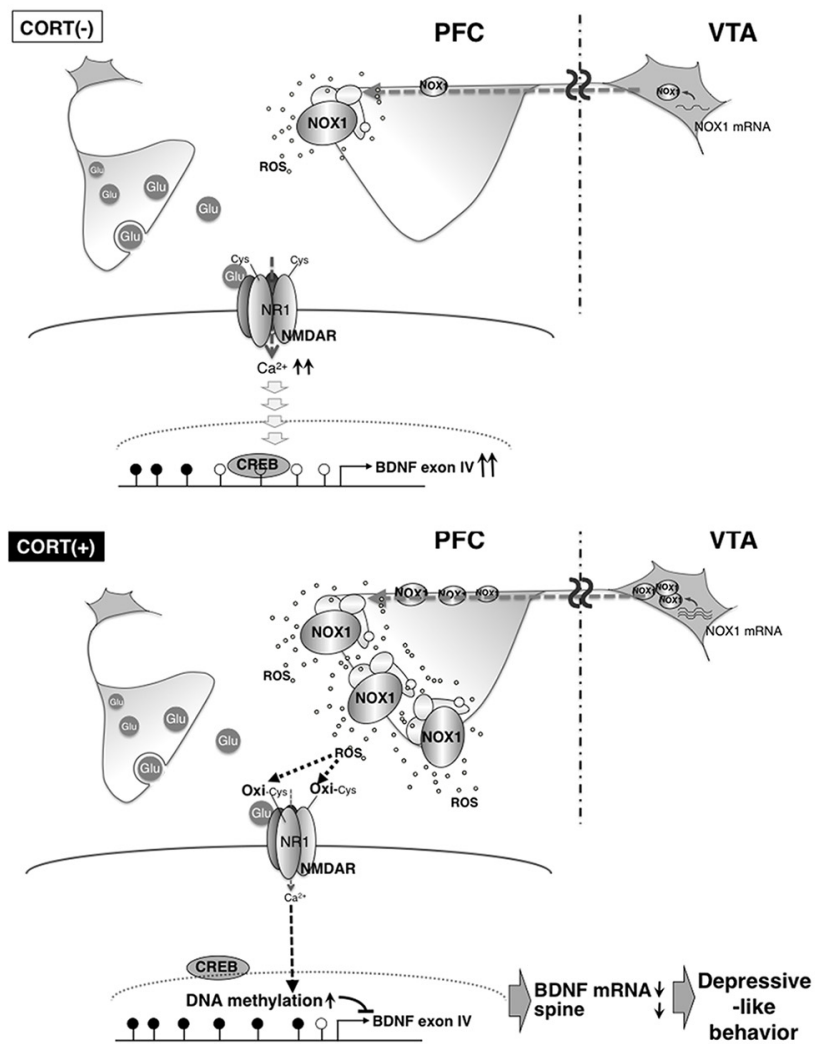

Figure 5. NR1 was a target molecule of NOX1-derived ROS in PFC. $A$, Levels of NR1, NR2B, and NSF mRNAs in PFC of mice treated with CORT. $B$, Assessment of the redox state of NR1 by the biotin pull-down assay. Top, NR1 bound to maleimide-(PEG) -biotin, which corresponds to the protein containing reduced cysteine residues. Bottom, Total NR1 in the lysate. The graph demonstrates the ratio of NR1 containing reduced cysteine residues to total NR1 following quantitative densitometric analyses. ${ }^{*} p<0.05$ compared with WT/CORT( - ) and \#\#p $<0.01$. C, Levels of exon IV-containing BDNF transcript in cortical neurons infected with lentivirus encoding NR1 or mutant NR1. ${ }^{* *} p<0.01$ compared with control and \#\#p $<0.01$, \#p $<0.05$ compared with NMDA alone. $\dagger+p<0.01$. D, A hypothetical model of NOX1-mediated depressive-like behaviors. CORT-induced upregulation of NOX1 mRNA in VTA elicits increased ROS generation in PFC. Oxidation of cysteine residues of NR1 attenuates NMDA receptor activity, leading to increased DNA methylation in the promoter region of the $b d n f$ gene, downregulation of BDNF, and the subsequent development of depressive-like behaviors. 
demonstrated between the two genotypes. Because increased NOX1 mRNA was sustained until $21 \mathrm{~d}$ of CORT treatment, constant upregulation of NOX1 may lead to augmented superoxide production in PFC. Previously, a pivotal role for VTA in susceptibility to chronic social defeat stress and antidepressant action was documented (Cao et al., 2010). Analyses of c-Fos expression of VTA dopamine neurons and dopamine turnover in PFC revealed a reduced mesocortical dopaminergic pathway in mice under repeated social defeat stress (Tanaka et al., 2012). Our data are therefore in line with the concept that the VTA-PFC projection plays a significant role in the regulation of depressive disorders.

The long-term administration of CORT significantly upregulated NOX1 mRNA in VTA but not in other brain areas. The reason why NOX1 was induced only in VTA was not clarified in this study. The induction of NOX1 by CORT took place after $14 \mathrm{~d}$ of treatment. Because no glucocorticoid response element was depicted in the mouse Noxl promoter, it is likely that CORT treatment indirectly affected NOX1 expression. Between the two dopaminergic projections originating from the VTA, the mesocortical and mesolimbic pathways, glucocorticoids were reported to selectively affect the mesocortical pathway (Niwa et al., 2013). VTA is strongly innervated by GABAergic, glutamatergic, and dopaminergic inputs from several brain regions (Polter and Kauer, 2014). The glucocorticoid receptor is located on glutamatergic neurons in PFC as well as on dopaminergic neuron in VTA. Under stress, the activation of glucocorticoid receptor induces the potentiation of glutamatergic synapses on VTA dopaminergic neuron, leading to dopamine efflux in PFC (Daftary et al., 2009; Butts and Phillips, 2013). These findings suggest that the effect of glucocorticoid is restricted to the mesocortical pathway. The restricted upregulation of NOX1 in VTA may therefore be associated with the projection-specific effects of glucocorticoids and downstream signaling cascades in dopamine neurons.

The administration of CORT significantly reduced transcript levels of the $b d n f$ gene with increased DNA methylation in the promoter region of exon IV. These changes were abolished in mice deficient in Nox1. The $b d n f$ gene contains multiple promoters that generate transcripts containing different 5 '-noncoding exons, all of which are coding the same protein (Pruunsild et al., 2007). Previous studies indicated that expression of the $b d n f$ gene is regulated by epigenetic modification (Tsankova et al., 2006; Roth et al., 2009). Among $b d n f$ exons, exon IV encompasses the transcription start site and cAMP response element (CRE). When we investigated the DNA methylation in the promoter region of exon IV, increased methylation in several CpGs located upstream of the transcriptional start site of exon IV was demonstrated in WT mice treated with CORT. Of particular interest was the finding that the methylation of $\mathrm{CpG}$ at -35 bp harboring CRE was almost completely absent in mice deficient in Nox1. Our findings thus suggest a role for NOX1-dependent DNA methylation in decreased expression of the exon IV mRNA induced by CORT.

Among candidate target molecules of NOX1-derived ROS depicted by redox proteome analyses, NR1 and NR2B constitute NMDA receptors, while NSF is involved in vesicle fusion events and neurotransmitter release from the presynaptic terminal (Söllner and Rothman, 1994). Some cysteine residues in NR1, including Cys744, are known to be redox sensitive, and oxidation of these residues reduces NMDA-gated currents (Sullivan et al., 1994; Choi et al., 2001). In the present proteome analyses, NOX1dependent oxidation of Cys744 of NR1 was demonstrated. The biotin pull-down assay indicated that reduced forms of cysteine in NR1 were indeed decreased in CORT-treated WT mice but not in $N o x 1^{-/ Y}$. Earlier findings that oxidization of NSF inhibits ex- ocytosis (Sullivan et al., 1994; Matsushita et al., 2005) further support the view that NMDA receptor-mediated synaptic transmission may be attenuated in CORT-treated WT mice. Importantly, neural activity-dependent BDNF gene expression is linked to the epigenetic regulation of $b d n f$ exon IV. Transcription initiated from the promoter region of BDNF exon IV was markedly activated in neurons treated with $\mathrm{KCl}$ (Chen et al., 2003; Martinowich et al., 2003), which was attributed to decreased methylation in the region corresponding to the $\mathrm{CpG}$ sites depicted in the present study. Because repeated stress or in vitro treatment of CORT depresses NMDA receptor-mediated synaptic transmission in PFC (Yuen et al., 2012), the NOX1-mediated attenuation of glutamatergic neurotransmission may lead to the increased DNA methylation and subsequent downregulation of BDNF (Fig. 5D).

The redox modification of NMDA receptor in PFC has been proposed for attention and cognition deficits during aging (Kumar and Foster, 2013; Guidi et al., 2015). NMDA receptor signaling is also implicated in the pathophysiology of schizophrenia (Coyle, 2012). Intriguingly, involvement of NADPH oxidase in psychosis induced by ketamine, an antagonist of NMDA receptor, was documented (Behrens et al., 2007). A disturbance of the NMDA receptor function by NADPH oxidase may therefore be a common mechanism underlying these neurological disorders. While the present findings highlight a causal link between NOX1 in the mesocortical pathway and depressive-like behaviors, other NOX isoforms in the neuronal circuitry that regulate emotional behaviors or cognition could play a role in different animal models. Further investigation is required to provide a comprehensive picture of the functional role of NADPH oxidase expressed in the brain. In any case, the present study provides the first evidence that NOX1/NADPH oxidase is the source of ROS leading to the depressive-like behaviors in animal models of MDD. The NOX1 isoform of the enzyme may thus become a potential target in pharmacological intervention for psychiatric disorders.

\section{References}

Behrens MM, Ali SS, Dao DN, Lucero J, Shekhtman G, Quick KL, Dugan LL (2007) Ketamine-induced loss of phenotype of fast-spiking interneurons is mediated by NADPH-oxidase. Science 318:1645-1647. CrossRef Medline

Berton O, McClung CA, Dileone RJ, Krishnan V, Renthal W, Russo SJ, Graham D, Tsankova NM, Bolanos CA, Rios M, Monteggia LM, Self DW, Nestler EJ (2006) Essential role of BDNF in the mesolimbic dopamine pathway in social defeat stress. Science 311:864-868. CrossRef Medline

Butts KA, Phillips AG (2013) Glucocorticoid receptors in the prefrontal cortex regulate dopamine efflux to stress via descending glutamatergic feedback to the ventral tegmental area. Int J Neuropsychopharmacol 16: 1799-1807. CrossRef Medline

Cao JL, Covington HE 3rd, Friedman AK, Wilkinson MB, Walsh JJ, Cooper DC, Nestler EJ, Han MH (2010) Mesolimbic dopamine neurons in the brain reward circuit mediate susceptibility to social defeat and antidepressant action. J Neurosci 30:16453-16458. CrossRef Medline

Chaudhury D, Walsh JJ, Friedman AK, Juarez B, Ku SM, Koo JW, Ferguson D, Tsai HC, Pomeranz L, Christoffel DJ, Nectow AR, Ekstrand M, Domingos A, Mazei-Robison MS, Mouzon E, Lobo MK, Neve RL, Friedman JM, Russo SJ, Deisseroth K, et al (2013) Rapid regulation of depressionrelated behaviours by control of midbrain dopamine neurons. Nature 493:532-536. CrossRef Medline

Chen WG, Chang Q, Lin Y, Meissner A, West AE, Griffith EC, Jaenisch R, Greenberg ME (2003) Derepression of BDNF transcription involves calcium-dependent phosphorylation of MeCP2. Science 302:885-889. CrossRef Medline

Choi Y, Chen HV, Lipton SA (2001) Three pairs of cysteine residues mediate both redox and $\mathrm{zn}^{2+}$ modulation of the NMDA receptor. J Neurosci 21:392-400. Medline 
Cook SC, Wellman CL (2004) Chronic stress alters dendritic morphology in rat medial prefrontal cortex. J Neurobiol 60:236-248. CrossRef Medline

Coyle JT (2012) NMDA receptor and schizophrenia: a brief history. Schizophr Bull 38:920-926. CrossRef Medline

Cui W, Matsuno K, Iwata K, Ibi M, Matsumoto M, Zhang J, Zhu K, Katsuyama M, Torok NJ, Yabe-Nishimura C (2011) NOX1/nicotinamide adenine dinucleotide phosphate, reduced form (NADPH) oxidase promotes proliferation of stellate cells and aggravates liver fibrosis induced by bile duct ligation. Hepatology 54:949-958. CrossRef Medline

Daftary SS, Panksepp J, Dong Y, Saal DB (2009) Stress-induced, glucocorticoiddependent strengthening of glutamatergic synaptic transmission in midbrain dopamine neurons. Neurosci Lett 452:273-276. CrossRef Medline

Dias-Ferreira E, Sousa JC, Melo I, Morgado P, Mesquita AR, Cerqueira JJ, Costa RM, Sousa N (2009) Chronic stress causes frontostriatal reorganization and affects decision-making. Science 325:621-625. CrossRef Medline

Duman CH, Duman RS (2015) Spine synapse remodeling in the pathophysiology and treatment of depression. Neurosci Lett 601:20-29. CrossRef Medline

Dwivedi Y, Rizavi HS, Pandey GN (2006) Antidepressants reverse corticosteronemediated decrease in brain-derived neurotrophic factor expression: differential regulation of specific exons by antidepressants and corticosterone. Neuroscience 139:1017-1029. CrossRef Medline

Gourley SL, Swanson AM, Koleske AJ (2013) Corticosteroid-induced neural remodeling predicts behavioral vulnerability and resilience. J Neurosci 33:3107-3112. CrossRef Medline

Guidi M, Kumar A, Foster TC (2015) Impaired attention and synaptic senescence of the prefrontal cortex involves redox regulation of NMDA receptors. J Neurosci 35:3966-3977. CrossRef Medline

Gupta D, Radhakrishnan M, Kurhe Y (2015) Effect of a novel 5-HT3 receptor antagonist 4i, in corticosterone-induced depression-like behavior and oxidative stress in mice. Steroids 96:95-102. CrossRef Medline

Hall DJ, Han SH, Chepetan A, Inui EG, Rogers M, Dugan LL (2012) Dynamic optical imaging of metabolic and NADPH oxidase-derived superoxide in live mouse brain using fluorescence lifetime unmixing. J Cereb Blood Flow Metab 32:23-32. CrossRef Medline

Ibi M, Matsuno K, Shiba D, Katsuyama M, Iwata K, Kakehi T, Nakagawa T, Sango K, Shirai Y, Yokoyama T, Kaneko S, Saito N, Yabe-Nishimura C (2008) Reactive oxygen species derived from NOX1/NADPH oxidase enhance inflammatory pain. J Neurosci 28:9486-9494. CrossRef Medline

Ibi M, Matsuno K, Matsumoto M, Sasaki M, Nakagawa T, Katsuyama M, Iwata K, Zhang J, Kaneko S, Yabe-Nishimura C (2011) Involvement of NOX1/NADPH oxidase in morphine-induced analgesia and tolerance. J Neurosci 31:18094-18103. CrossRef Medline

Januar V, Saffery R, Ryan J (2015) Epigenetics and depressive disorders: a review of current progress and future directions. Int J Epidemiol 44: 1364-1387. CrossRef Medline

Johnson SA, Fournier NM, Kalynchuk LE (2006) Effect of different doses of corticosterone on depression-like behavior and HPA axis responses to a novel stressor. Behav Brain Res 168:280-288. CrossRef Medline

Kang HJ, Voleti B, Hajszan T, Rajkowska G, Stockmeier CA, Licznerski P, Lepack A, Majik MS, Jeong LS, Banasr M, Son H, Duman RS (2012) Decreased expression of synapse-related genes and loss of synapses in major depressive disorder. Nat Med 18:1413-1417. CrossRef Medline

Kim KS, Han PL (2006) Optimization of chronic stress paradigms using anxiety- and depression-like behavioral parameters. J Neurosci Res 83: 497-507. CrossRef Medline

Kumar A, Foster TC (2013) Linking redox regulation of NMDAR synaptic function to cognitive decline during aging. J Neurosci 33:15710-15715. CrossRef Medline

Lehmann ML, Brachman RA, Martinowich K, Schloesser RJ, Herkenham M (2013) Glucocorticoids orchestrate divergent effects on mood through adult neurogenesis. J Neurosci 33:2961-2972. CrossRef Medline

Liston C, Miller MM, Goldwater DS, Radley JJ, Rocher AB, Hof PR, Morrison JH, McEwen BS (2006) Stress-induced alterations in prefrontal cortical dendritic morphology predict selective impairments in perceptual attentional set-shifting. J Neurosci 26:7870-7874. CrossRef Medline

Maes M, Galecki P, Chang YS, Berk M (2011) A review on the oxidative and nitrosative stress (O\&NS) pathways in major depression and their possible contribution to the (neuro)degenerative processes in that illness. Prog Neuropsychopharmacol Biol Psychiatry 35:676-692. CrossRef Medline
Martinowich K, Hattori D, Wu H, Fouse S, He F, Hu Y, Fan G, Sun YE (2003) DNA methylation-related chromatin remodeling in activity-dependent BDNF gene regulation. Science 302:890-893. CrossRef Medline

Matsuno K, Yamada H, Iwata K, Jin D, Katsuyama M, Matsuki M, Takai S, Yamanishi K, Miyazaki M, Matsubara H, Yabe-Nishimura C (2005) Noxl is involved in angiotensin II-mediated hypertension: a study in Nox1-deficient mice. Circulation 112:2677-2685. CrossRef Medline

Matsushita K, Morrell CN, Mason RJ, Yamakuchi M, Khanday FA, Irani K, Lowenstein CJ (2005) Hydrogen peroxide regulation of endothelial exocytosis by inhibition of $\mathrm{N}$-ethylmaleimide sensitive factor. J Cell Biol 170:73-79. CrossRef Medline

McEwen BS, Nasca C, Gray JD (2016) Stress effects on neuronal structure: hippocampus, amygdala, and prefrontal cortex. Neuropsychopharmacology 41:3-23. CrossRef Medline

Morales-Medina JC, Sanchez F, Flores G, Dumont Y, Quirion R (2009) Morphological reorganization after repeated corticosterone administration in the hippocampus, nucleus accumbens and amygdala in the rat. J Chem Neuroanat 38:266-272. CrossRef Medline

Mori H, Matsuda KI, Tsukahara S, Kawata M (2010) Intrauterine position affects estrogen receptor alpha expression in the ventromedial nucleus of the hypothalamus via promoter DNA methylation. Endocrinology 151: 5775-5781. CrossRef Medline

Ng F, Berk M, Dean O, Bush AI (2008) Oxidative stress in psychiatric disorders: evidence base and therapeutic implications. Int J Neuropsychopharmacol 11:851-876. CrossRef Medline

Niwa M, Jaaro-Peled H, Tankou S, Seshadri S, Hikida T, Matsumoto Y, Cascella NG, Kano S, Ozaki N, Nabeshima T, Sawa A (2013) Adolescent stress-induced epigenetic control of dopaminergic neurons via glucocorticoids. Science 339:335-339. CrossRef Medline

Polter AM, Kauer JA (2014) Stress and VTA synapses: implications for addiction and depression. Eur J Neurosci 39:1179-1188. CrossRef Medline

Price JL, Drevets WC (2010) Neurocircuitry of mood disorders. Neuropsychopharmacology 35:192-216. CrossRef Medline

Price JL, Drevets WC (2012) Neural circuits underlying the pathophysiology of mood disorders. Trends Cogn Sci 16:61-71. CrossRef Medline

Pruunsild P, Kazantseva A, Aid T, Palm K, Timmusk T (2007) Dissecting the human BDNF locus: bidirectional transcription, complex splicing, and multiple promoters. Genomics 90:397-406. CrossRef Medline

Quick KL, Ali SS, Arch R, Xiong C, Wozniak D, Dugan LL (2008) A carboxyfullerene SOD mimetic improves cognition and extends the lifespan of mice. Neurobiol Aging 29:117-128. CrossRef Medline

Radley JJ, Sisti HM, Hao J, Rocher AB, McCall T, Hof PR, McEwen BS, Morrison JH (2004) Chronic behavioral stress induces apical dendritic reorganization in pyramidal neurons of the medial prefrontal cortex. Neuroscience 125:1-6. CrossRef Medline

Radley JJ, Rocher AB, Miller M, Janssen WG, Liston C, Hof PR, McEwen BS, Morrison JH (2006) Repeated stress induces dendritic spine loss in the rat medial prefrontal cortex. Cereb Cortex 16:313-320. CrossRef Medline

Roth TL, Lubin FD, Funk AJ, Sweatt JD (2009) Lasting epigenetic influence of early-life adversity on the BDNF gene. Biol Psychiatry 65:760-769. CrossRef Medline

Seo JS, Park JY, Choi J, Kim TK, Shin JH, Lee JK, Han PL (2012) NADPH oxidase mediates depressive behavior induced by chronic stress in mice. J Neurosci 32:9690-9699. CrossRef Medline

Shimizu E, Hashimoto K, Okamura N, Koike K, Komatsu N, Kumakiri C, Nakazato M, Watanabe H, Shinoda N, Okada S, Iyo M (2003) Alterations of serum levels of brain-derived neurotrophic factor (BDNF) in depressed patients with or without antidepressants. Biol Psychiatry 54: 70-75. CrossRef Medline

Söllner T, Rothman JE (1994) Neurotransmission: harnessing fusion machinery at the synapse. Trends Neurosci 17:344-348. CrossRef Medline

Sorce S, Krause KH (2009) NOX enzymes in the central nervous system: from signaling to disease. Antioxid Redox Signal 11:2481-2504. CrossRef Medline

Sullivan JM, Traynelis SF, Chen HS, Escobar W, Heinemann SF, Lipton SA (1994) Identification of two cysteine residues that are required for redox modulation of the NMDA subtype of glutamate receptor. Neuron 13: 929-936. CrossRef Medline

Tanaka K, Furuyashiki T, Kitaoka S, Senzai Y, Imoto Y, Segi-Nishida E, Deguchi Y, Breyer RM, Breyer MD, Narumiya S (2012) Prostaglandin 
E2-mediated attenuation of mesocortical dopaminergic pathway is critical for susceptibility to repeated social defeat stress in mice. J Neurosci 32:4319-4329. CrossRef Medline

Thompson Ray M, Weickert CS, Wyatt E, Webster MJ (2011) Decreased BDNF, trkB-TK+ and GAD67 mRNA expression in the hippocampus of individuals with schizophrenia and mood disorders. J Psychiatry Neurosci 36:195-203. CrossRef Medline

Tian F, Hu XZ, Wu X, Jiang H, Pan H, Marini AM, Lipsky RH (2009) Dynamic chromatin remodeling events in hippocampal neurons are associated with NMDA receptor-mediated activation of Bdnf gene promoter 1 . J Neurochem 109:1375-1388. CrossRef Medline

Tiscornia G, Singer O, Verma IM (2006) Production and purification of lentiviral vectors. Nat Protoc 1:241-245. CrossRef Medline

Tsankova NM, Berton O, Renthal W, Kumar A, Neve RL, Nestler EJ (2006)
Sustained hippocampal chromatin regulation in a mouse model of depression and antidepressant action. Nat Neurosci 9:519-525. CrossRef Medline

Yuen EY, Wei J, Liu W, Zhong P, Li X, Yan Z (2012) Repeated stress causes cognitive impairment by suppressing glutamate receptor expression and function in prefrontal cortex. Neuron 73:962-977. CrossRef Medline

Zhang JC, Wu J, Fujita Y, Yao W, Ren Q, Yang C, Li SX, Shirayama Y, Hashimoto K (2014) Antidepressant effects of TrkB ligands on depression-like behavior and dendritic changes in mice after inflammation. Int J Neuropsychopharmacol 18:pyu077. CrossRef Medline

Zlatković J, Todorović N, Bošković M, Pajović SB, Demajo M, Filipović D (2014) Different susceptibility of prefrontal cortex and hippocampus to oxidative stress following chronic social isolation stress. Mol Cell Biochem 393:43-57. CrossRef Medline 